\title{
GABAergic Cells Are the Major Postsynaptic Targets of Mossy Fibers in the Rat Hippocampus
}

\author{
László Acsády, ${ }^{1,2}$ Anita Kamondi, ${ }^{1}$ Attila Sík, ${ }^{2}$ Tamás Freund, ${ }^{2}$ and György Buzsáki ${ }^{1}$ \\ ${ }^{1}$ Center for Molecular and Behavioral Neuroscience, Rutgers, The State University of New Jersey, Newark, New Jersey \\ 07102, and 2Institute of Experimental Medicine, Hungarian Academy of Sciences, H-1450 Budapest, Hungary
}

\begin{abstract}
Dentate granule cells communicate with their postsynaptic targets by three distinct terminal types. These include the large mossy terminals, filopodial extensions of the mossy terminals, and smaller en passant synaptic varicosities. We examined the postsynaptic targets of mossy fibers by combining in vivo intracellular labeling of granule cells, immunocytochemistry, and electron microscopy. Single granule cells formed large, complex "mossy" synapses on 11-15 CA3 pyramidal cells and 7-12 hilar mossy cells. In contrast, GABAergic interneurons, identified with immunostaining for substance P-receptor, parvalbumin, and mGluR1a-receptor, were selectively innervated by very thin (filopodial) extensions of the mossy terminals and by small en passant boutons in both the hilar and CA3 regions. These terminals formed single, often perforated, asymmetric
\end{abstract}

synapses on the cell bodies, dendrites, and spines of GABAergic interneurons. The number of filopodial extensions and small terminals was 10 times larger than the number of mossy terminals. These findings show that in contrast to cortical pyramidal neurons, (1) granule cells developed distinct types of terminals to affect interneurons and pyramidal cells and (2) they innervated more inhibitory than excitatory cells. These findings may explain the physiological observations that increased activity of granule cells suppresses the overall excitability of the CA3 recurrent system and may form the structural basis of the target-dependent regulation of glutamate release in the mossy fiber system.

Key words: granule cell; mossy fiber; interneuron; spine; dentate gyrus; in vivo
A unique neuron type of cortical structures is the dentate granule cell of the archicortex. Granule cells receive most of their extrinsic input from layer II neurons of the entorhinal cortex and convey neocortical representations to the recurrent system of the hippocampal CA3 region by way of their axons, known as mossy fibers (Ramón y Cajal, 1911; Steward and Scoville, 1976; Claiborne et al., 1986). Collaterals of the same entorhinal afferents also directly innervate the distal dendrites of CA3 pyramidal cells (Steward and Scoville, 1976). The entorhinal projections to both granule cells and CA3 cells are very divergent. In contrast, a single granule cell contacts only a few dozen hilar mossy cells and CA3 pyramidal cells, and the convergence of granule cells on their principal cell targets is similarly limited (Amaral et al., 1990). The target mossy cells and CA3 pyramidal cells provide a highly divergent feedback excitation to the granule cells ( $\mathrm{Li}$ et al., 1994; Scharfman, 1994; Soriano and Frotscher, 1994; Buckmaster et al., 1996). Despite these excitatory loops, activation of the entorhinal-granule cell network appears to exert an overall suppressive effect on CA3 pyramidal neurons (Bragin et al., 1995a,b; Penttonen et al., 1997) as opposed to the overall excitatory effect of the CA3 recurrent network on all other regions of the hippocampal formation (Chrobak and Buzsáki, 1996; Penttonen et

Received Dec. 19, 1997; revised Feb. 11, 1998; accepted Feb. 16, 1998.

This work was supported by the National Institute of Neurological Diseases and Stroke (NS34994), the National Institute of Mental Health (MH 54671), the OTKA (T16942), the Human Frontier Science Program, the Whitehall Foundation, the Soros Foundation, and the Howard Hughes Medical Institute. We thank M. Penttonen for performing some of the intracellular experiments, L. Záborszky, Z. Nádasdy, E. Borók, H. Oliviera, and G. Goda for support, and T. Gorcs, J. H. Rogers, and R. Shigemoto for the antibody gifts.

Correspondence should be addressed to György Buzsáki, Center for Molecular and Behavioral Neuroscience, Rutgers University, 197 University Avenue, Newark, NJ 07102.

Copyright (ㄷ) 1998 Society for Neuroscience $\quad 0270-6474 / 98 / 183386-18 \$ 05.00 / 0$ al., 1997). The possible anatomical basis of this functional suppression might be a strong feed-forward activation of inhibitory interneurons by granule cells (Frotscher, 1985, 1989; Gulyás et al., 1992; Deller et al., 1994).

The physiological effects of granule cells on interneurons are different from those on principal cells (Miles, 1990; Scharfman et al., 1990; Livsey and Vicini, 1992; Jonas et al., 1993; Geiger et al., 1997; Maccaferri et al., 1998). Whether this difference is reflected in the structure of excitatory terminals or in the number of release sites on different postsynaptic cell types has yet to be demonstrated. Interestingly, Ramón y Cajal (1911) noted a unique feature of mossy fibers: that unlike any other cortical principal cell, granule cells have more than one terminal type along their axons. In addition to the well known mossy terminals, which form intricate multiple contacts with principal cells (Blackstad and Kjaerheim, 1961; Chicurel and Harris, 1992), small terminals and filopodial extensions of the mossy terminals have also been described (Ramón y Cajal, 1911). More recently, these various smaller extensions of the mossy fibers were also identified as presynaptic terminals (Amaral, 1979; Claiborne et al., 1986). Although the small terminals may outnumber the well characterized large mossy terminals, identification of their postsynaptic targets has not been attempted to date.

In the present study, we combined in vivo intracellular labeling of granule cells with immunocytochemistry and electron microscopy to answer the following questions. Are the different types of axon terminals associated with different postsynaptic neuronal populations? Is the proportion of principal cells versus inhibitory interneurons innervated by a single granule cell similar to or different from that in other cortical networks? What kind of interneurons are innervated by the granule cells? Do neighboring granule cells share common principal and interneuron targets? 
Are the number of neurotransmitter release sites similar on the different neuronal targets? We attempted to answer these questions quantitatively within the limits afforded by the single cell labeling and immunocytochemical methods.

\section{MATERIALS AND METHODS}

Surgery and recording. Twenty-one rats of the Sprague Dawley strain $(250-350 \mathrm{gm})$ were anesthetized with urethane $(1.3-1.5 \mathrm{gm} / \mathrm{kg})$ and placed in a stereotaxic apparatus. The body temperature of the rat was kept constant by a thermoregulation device. The scalp was removed and a small $(1.2 \times 0.8 \mathrm{~mm})$ bone window was drilled above the hippocampus (anteromedial edge at anterioposterior $=-3.3$; lateral $=2.2 \mathrm{~mm}$ from bregma) for extra- and intracellular recordings. Details of surgery and electrode placement have been published previously (Penttonen et al., 1997). Briefly, glass micropipettes for intracellular labeling were pulled from $2.0 \mathrm{~mm}$ capillary glass. They were filled with $1 \mathrm{M} \mathrm{K}^{+}$-acetate in 50 mM Tris buffer, $\mathrm{pH} 7.2$, also containing $2 \%$ biocytin for intracellular labeling. After the recording pipette was inserted into the brain, the bone window was covered by a mixture of paraffin and paraffin oil to prevent drying of the brain and to decrease pulsation. Once a stable intracellular recording was obtained, evoked and passive physiological properties of the cell were determined (Axoclamp-2B; Axon Instruments, Foster City, CA). After the completion of the physiological data collection (Penttonen et al., 1997), biocytin was injected through a bridge circuit using $500 \mathrm{msec}$ depolarizing pulses at $0.4-0.7 \mathrm{nA}$ at $1 \mathrm{~Hz}$ for $10-60 \mathrm{~min}$. Neuronal activity was followed throughout the procedure, and the current was reduced if the electrode was blocked and the condition of the neuron had deteriorated. In some cases small spikelets were recorded in addition to the regular large amplitude action potentials. In all of these cases histological analysis revealed multiple labeling of granule cells (two or three neurons). These artificially labeled cells were also included in this study, because they provided an opportunity to examine the topography and convergence of mossy fibers of nearby granule cells.

Histological analysis. Two to twelve hours after the biocytin injection, the animals were given an overdose of urethane and then perfused intracardially with physiological saline followed by $400 \mathrm{ml}$ fixative containing $4 \%$ paraformaldehyde dissolved in $0.1 \mathrm{M}$ phosphate buffer (PB), $\mathrm{pH} 7.4$ (fixative A). In four cases, after the saline the animals were perfused with $60 \mathrm{ml}$ fixative containing $3.75 \%$ acrolein and $2 \%$ paraformaldehyde $(5 \mathrm{~min})$ in $0.1 \mathrm{M} \mathrm{PB}$ and then with $300 \mathrm{ml} 2 \%$ paraformaldehyde in $0.1 \mathrm{M}$ PB (fixative B). The brains were then removed and stored in the fixative solution overnight. Coronal sections ( 40 or $60 \mu \mathrm{m}$ thick) were cut from the hippocampus on a Vibroslice, washed, cryoprotected in $30 \%$ sucrose in $0.1 \mathrm{M}$ PB overnight, and freeze-thawed in aluminum foil boats over liquid nitrogen. The sections were treated with $1 \%$ sodium borohydride when fixative B was used. After extensive washes first in PB and then in Tris-buffered saline (TBS), pH 7.4, the sections were incubated in avidin-biotin horseradish peroxidase complex (ABC, Vector Laboratories, Burlingame, CA) (1.5 hr, 1:150). Biocytin labeling was visualized by nickel-intensified 3,3'-diaminobenzidine-4HCl (DAB) (Sigma, St. Louis, MO) as a chromogen, which resulted in a black reaction product. The DAB solution contained ammonium chloride $(0.4 \%)$ to reduce background. The sections were then treated with $1 \%$ $\mathrm{OsO}_{4}$ in $0.1 \mathrm{M} \mathrm{PB}$ for $45 \mathrm{~min}$, dehydrated in ethanol and propylene oxide, and embedded in Durcupan (ACM, Fluka; Neu Ulm, Germany).

Three-dimensional reconstruction of the main axons was accomplished in four cases using motorized microscope stage and the program NeuroLucida (MicroBrightfield, Colchester, VT) or in another three cases using the program Arbor (S. Pomaházi and A. I. Gulyás, Budapest, Hungary). The latter creates a pseudo three-dimensional image from camera lucida drawings. After the reconstruction of the axon, its length and the distances between mossy terminals in the three-dimensional space were determined. Long mossy fiber segments, parallel to the surface, were selected and re-embedded for further electron microscopic examination. Serial ultrathin sections were cut with a Reichert ultramicrotome and examined with a Philips CM 10 or Hitachi 7100 electron microscope.

Immunostaining procedure. For the examination of the axonal targets of the filled granule cells, the sections were not dehydrated after the first $\mathrm{ABC}$ reaction but were processed with additional antibodies. To reduce nonspecific staining, the sections were incubated with $10 \%$ normal goat serum (Vector Laboratories) for 40 min. Rabbit anti-substance-P (SPR) (1:3000; gift of Dr. R. Shigemoto; four cases) (Shigemoto et al., 1993;), rabbit anti-parvalbumin (1:2000; gift of Dr. K. G. Baimbridge; two cases)
(Baimbridge and Miller, 1982), rabbit anti-calretinin (1:5000; gift of Dr. J. H. Rogers; one case) (Rogers, 1989), or mouse anti-metabotropic glutamate receptor 1a (mGluR1a 1:10; gift of Dr. T. Görcs; one case) was used as primary antisera for $2 \mathrm{~d}$. The second layer was biotinylated anti-rabbit $\operatorname{IgG}$ made in goat or biotinylated anti-mouse $\operatorname{IgG}$ made in horse (Vector Laboratories) $(1: 200 ; 6 \mathrm{hr}$ ) followed by ABC (Vector Laboratories) (overnight; 1:200). All washes and dilutions of antisera were performed in $0.05 \mathrm{~m}$ Tris-buffered saline (TBS), $\mathrm{pH}$ 7.4. The immunoperoxidase reaction was developed with DAB as a chromogen, resulting in a brown reaction product. Replacement of the primary antisera with normal sera of the animals, in which the primary antisera were raised, resulted in lack of immunostaining. Next, the sections were treated with $1 \% \mathrm{OsO}_{4}$ (containing $7 \%$ glucose to preserve color difference) in $0.1 \mathrm{M}$ PB for $45 \mathrm{~min}$, dehydrated in ethanol and propylene oxide, and embedded in Durcupan (ACM, Fluka, Buchs, Switzerland). The axon terminals of the granule cells and their close appositions with a flat surface toward a target soma, dendrite, or spine (i.e., putative synapses) were examined under a $100 \times$ oil immersion objective. In several cases, the dendritic tree of the putative postsynaptic target(s) was also reconstructed to determine the number of contacts with a single postsynaptic neuron and to measure the distance of the contact from the soma. Correlated light and electron microscopy were used in 42 cases to verify the synaptic specialization between the labeled profiles.

The size of presynaptic terminals of granule cells on their GABAergic target neurons was examined by pre-embedding gold immunostaining for dynorphin (a marker of mossy fibers and terminals) (McLean et al., 1987; Drake et al., 1994) combined with pre-embedding DAB reaction for SPR ( $p=3$ rats). Sections were incubated first with rabbit anti-dynorphin antibody (1:8000; Peninsula Labs) followed by anti-rabbit antiserum conjugated to $1 \mathrm{~nm}$ gold particles (1:40; overnight) (Amersham, Little Chalfont, UK). The colloidal gold was visualized by IntenS EM Silver Enhancement Kit (Amersham), and the reaction was terminated by $1 \%$ sodium thiosulfate and fixed with $1 \%$ glutaraldehyde for $10 \mathrm{~min}$. The sections were processed further for SPR immunocytochemistry as described above. In the electron microscope, the end product of the preembedding immunostaining appeared as high-contrast electron-dense granules, whereas the reaction product of DAB was less electron dense and homogeneously filled the profiles.

\section{RESULTS}

The passive and synaptic properties of the intracellularly recorded granule cells have been reported previously (Ylinen et al., 1995; Penttonen et al., 1997). Figure 1 illustrates the dendritic arbor of a biocytin-filled granule cell and its local axon collaterals in the hilar region. Both large mossy terminals and various small terminals could be visualized as described before in Golgi preparations (Ramón y Cajal, 1911) and in vitro studies (Claiborne et al., 1986). The terminology of Lorente de Nó (1934) and Amaral (1978) is used in this paper. Axon trajectories, terminal specializations, and postsynaptic targets of labeled granule cells will be described first in the CA3 region, followed by a similar description in the hilus.

\section{Axonal trajectory of the main mossy fiber}

A total of 28 granule cells with significant axonal labeling were included in this study. In 14 cases the axon arbor was judged as complete. Criteria for complete axonal labeling were twofold: the appearance of (1) sharp endings of all side branches without fading within the section and (2) terminal-like swelling (bouton) at the end of each axon branch. The average three-dimensional length of the main axon of granule cells, the "mossy" fiber, was $3236 \pm 72 \mu \mathrm{m}$ (SE; $n=>7$ cells), of which $802 \pm 21 \mu \mathrm{m}$ was in CA3c (hilar), $1051 \pm 15 \mu \mathrm{m}$ was in CA3b (ventricular), and $1396 \pm 91 \mu \mathrm{m}$ was in CA3a (fimbrial). Regardless of the position of the parent cell body (dorsal blade, ventral blade, tip or crest of the granule cell layer), the main axon trunk traveled septally in the CA3c and CA3b subregions, turned caudally at the distal end of CA3b, and followed a caudal route in CA3a (Fig. 2), as suggested by previous bulk injections and Golgi-staining studies 


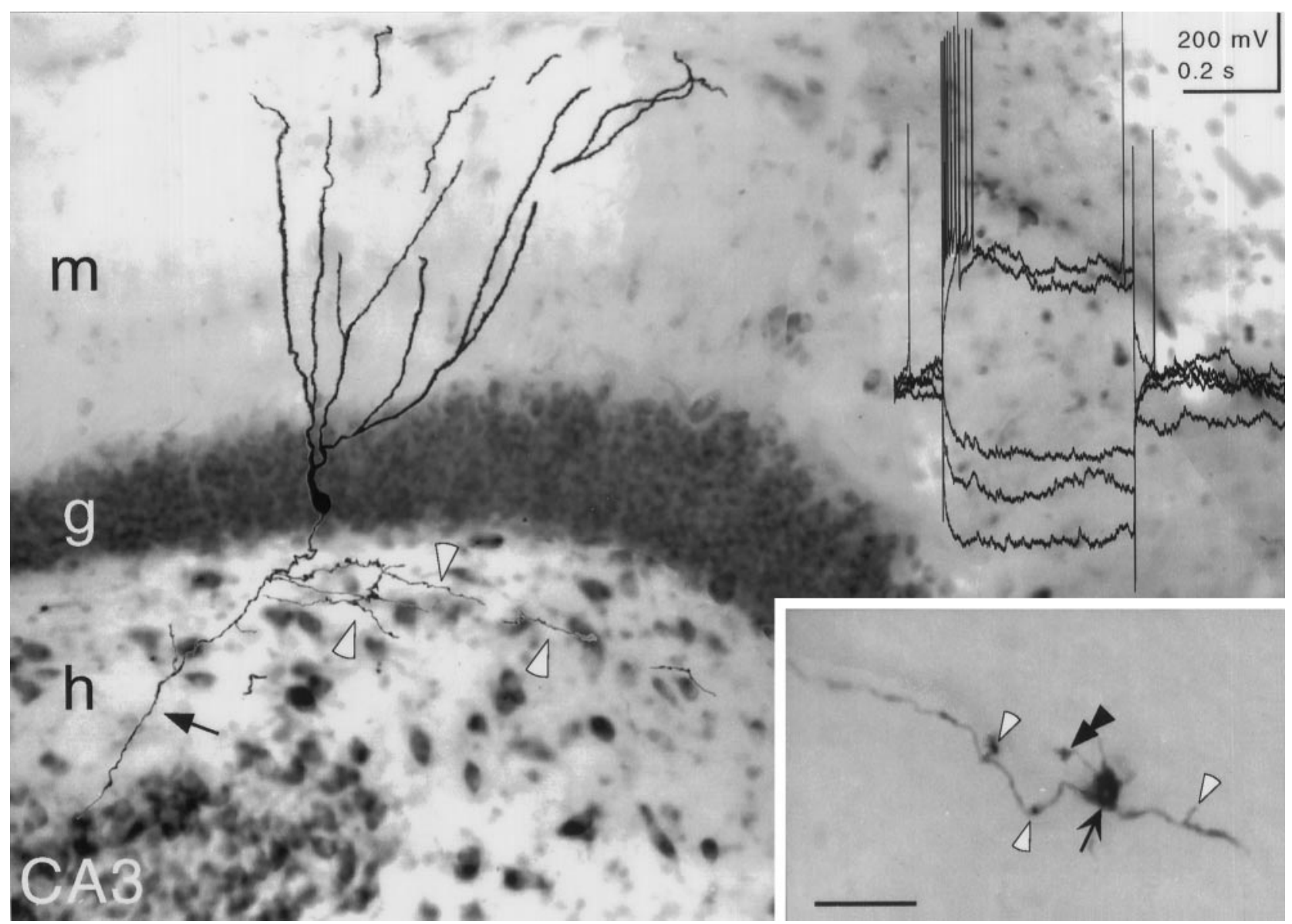

Figure 1. Granule cell filled with biocytin in vivo. The cell was first developed for biocytin and photographed, and the image was fused with the cresyl violet-stained image of the same section. Arrow indicates mossy fiber; white arrowheads indicate local collaterals in the hilar region. $m$, Molecular layer; $g$, granule cell layer; $h$, hilus; $C A 3$, pyramidal layer of CA3c. Top inset, Current-voltage responses of the granule cell to hyperpolarizing ( $-0.8,-0.6$, and $-0.4 \mathrm{nA}$ ) and depolarizing (0.7 and $0.8 \mathrm{nA})$ current steps. Bottom inset, High magnification of a mossy terminal (arrow) in the hilar region. Double arrowhead indicates filopodial extension; white arrowheads indicate small en passant and drumstick-like boutons. Scale bar, $10 \mu \mathrm{m}$.

(Ramón y Cajal, 1911; Swanson et al., 1978; Amaral and Witter, 1989). The septotemporal span of the main axon in the coronal plane was $1.1 \pm 0.5 \mathrm{~mm}(n=12 ; 0.9 \pm 0.05 \mathrm{~mm}$ septal and $0.2 \pm$ $0.05 \mathrm{~mm}$ caudal to the cell body). The largest septal extension (1.3 $\mathrm{mm}$ ) was measured in a granule cell with its cell body sitting in the crest region. In contrast, the axon trunk of granule cells situated at the tip of the dorsal blade had the shortest septal route and terminated most caudally. In general, mossy fibers followed the transversal axis of the hippocampus in the $\mathrm{CA} 3 \mathrm{c}-\mathrm{b}$ regions but ran along the longitudinal axis in area CA3a (Fig. 2). Thus, the mossy fiber system could be considered "lamellar" (Amaral and Witter, 1989) only in the CA3c-b regions. In area CA3a the mossy axons ran perpendicular to the "lamellae."

Most mossy fibers ran in stratum lucidum and only occasionally penetrated the CA3c pyramidal layer. Apart from one occasional side branch in $\mathrm{CA} 3 \mathrm{c}$, which joined the hilar plexus (see below) and short, thin stalks with a mossy terminal (Fig. 2A), mossy fibers did not have branchpoints along their length. When neighboring granule cells were labeled, their axons followed a relatively parallel route (Fig. 2). The distance between the axons of neighboring granule cells varied between 50 and $300 \mu \mathrm{m}$. Adjacent or nearby mossy boutons $(<50 \mu \mathrm{m})$ from two or more axons were never observed ( $p=58$ boutons). Given the diameter of the the apical dendrite of CA3 pyramidal cells $(p<10 \mu \mathrm{m})$, these findings indicated that the probability that adjacent granule cells innervate the same or nearby pyramidal cells is low.

\section{Mossy fibers have different terminal types}

Three basic types of terminals were encountered along the main axon of granule cells: large mossy terminals $(4-10 \mu \mathrm{m})$, filopodial extensions of mossy boutons $(0.5-2.0 \mu \mathrm{m})$, and small en passant varicosities $(0.5-2.0 \mu \mathrm{m})$. The latter two will be referred to as "small" terminals (Fig. 3). These small terminals of granule cells were somewhat larger than the varicosities of CA3 pyramidal neurons (Fig. 3; see Figs. 5, 6) (Sík et al., 1993).

Mossy terminals varied greatly in shape and size. In addition to the frequent, large single-headed terminals, double-headed and elongated mossy terminals consisting of three to five bulbous expansions were also found. Mossy terminals were either in en passant position or they were connected to the parent axon by a small side branch (1-30 $\mu \mathrm{m}$ long) (Fig. $2 A$ ). The total number of mossy terminals along the main axon in the CA3 region varied from 10 to 18 (average, $12.3 \pm 0.9$ ). They were distributed equally in the three subregions $(\mathrm{CA} 3 \mathrm{c}, 3.3 \pm 0.25$; CA3b, $4.1 \pm 0.31$; CA3a, $4.1 \pm 0.4)$. However, the interval between mossy terminals increased significantly in the CA3c to CA3a direction (CA3c, $162 \pm 12.6 \mu \mathrm{m} ; \mathrm{CA} 3 \mathrm{~b}, 223 \pm 19.0 \mu \mathrm{m} ; \mathrm{CA} 3 \mathrm{a}, 345 \pm 27.5 \mu \mathrm{m})$, as indicated by ANOVA $\left(F_{(2,68)}=18.17 ; p<0.001\right)$. These findings 

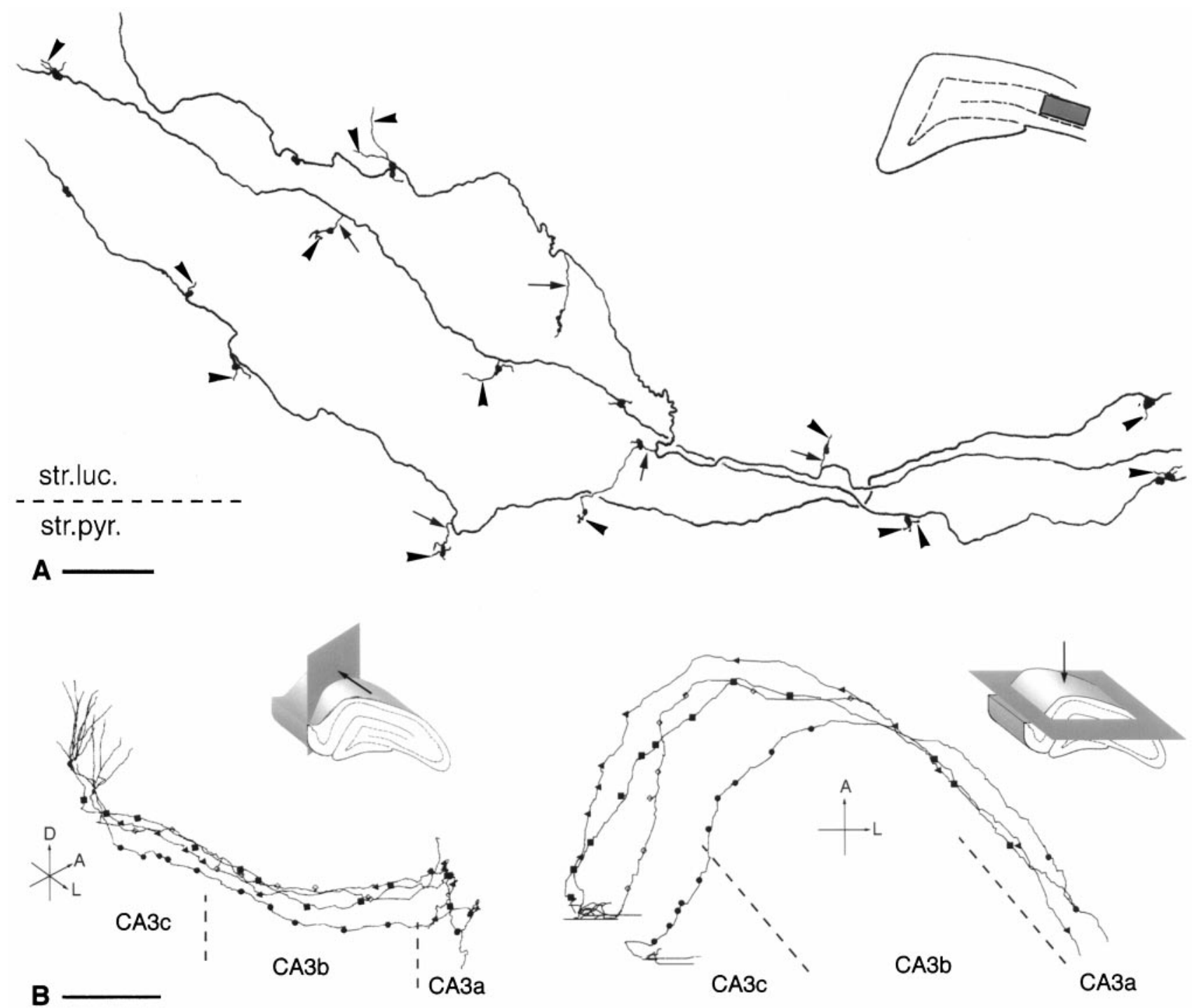

B САЗа CA3C

САЗа

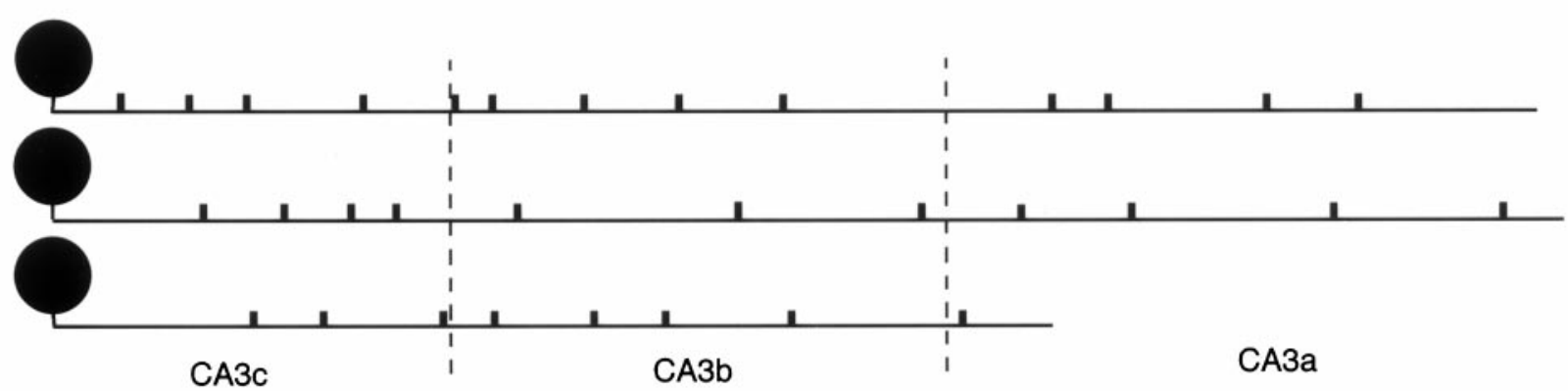

C

Figure 2. Topography of the mossy fibers in the CA3 region. A, Camera lucida drawing of mossy fibers of three adjacent (multiple-labeled) granule cells. Note numerous filopodial extensions of the large mossy terminals in $A$ (arrowheads) and thin stalks of large mossy terminals (arrows). Boxed area in inset in $A$ shows the position of the fibers at the CA3c-CA3b border. $B$, NeuroLucida reconstruction of the same three axons shown in $A$ (diamonds, triangles, and squares label mossy terminals) and an additional mossy fiber of a fourth granule cell (circles) located posterior to the triple-labeled neurons. The original coronal images are rotated to emphasize the spatial characteristics of the fibers. In the transversal view (left), fibers are visible only in $C A 3 c$ and $C A 3 b$, because in $C A 3 a$ they run perpendicular to this plane. In the dorsal view (right), the entire semicircular route of the mossy fibers can be followed. Note the parallel organization of the fibers. Insets show the angles of view (arrows) on a coronal block. $D$, Dorsal; $A$, anterior; $L$, lateral. $C$, Wire diagram of the three mossy fibers shown in $A$ (two of them are considered as complete) depicting the distribution of mossy terminals. Note that shorter interbouton distances prevail in the CA3c subregion. Scale bars: $A, 50 \mu \mathrm{m} ; B, 400 \mu \mathrm{m} ; C, 200 \mu \mathrm{m}$. str.luc., Stratum lucidum; str.pyr., stratum pyramidale. 

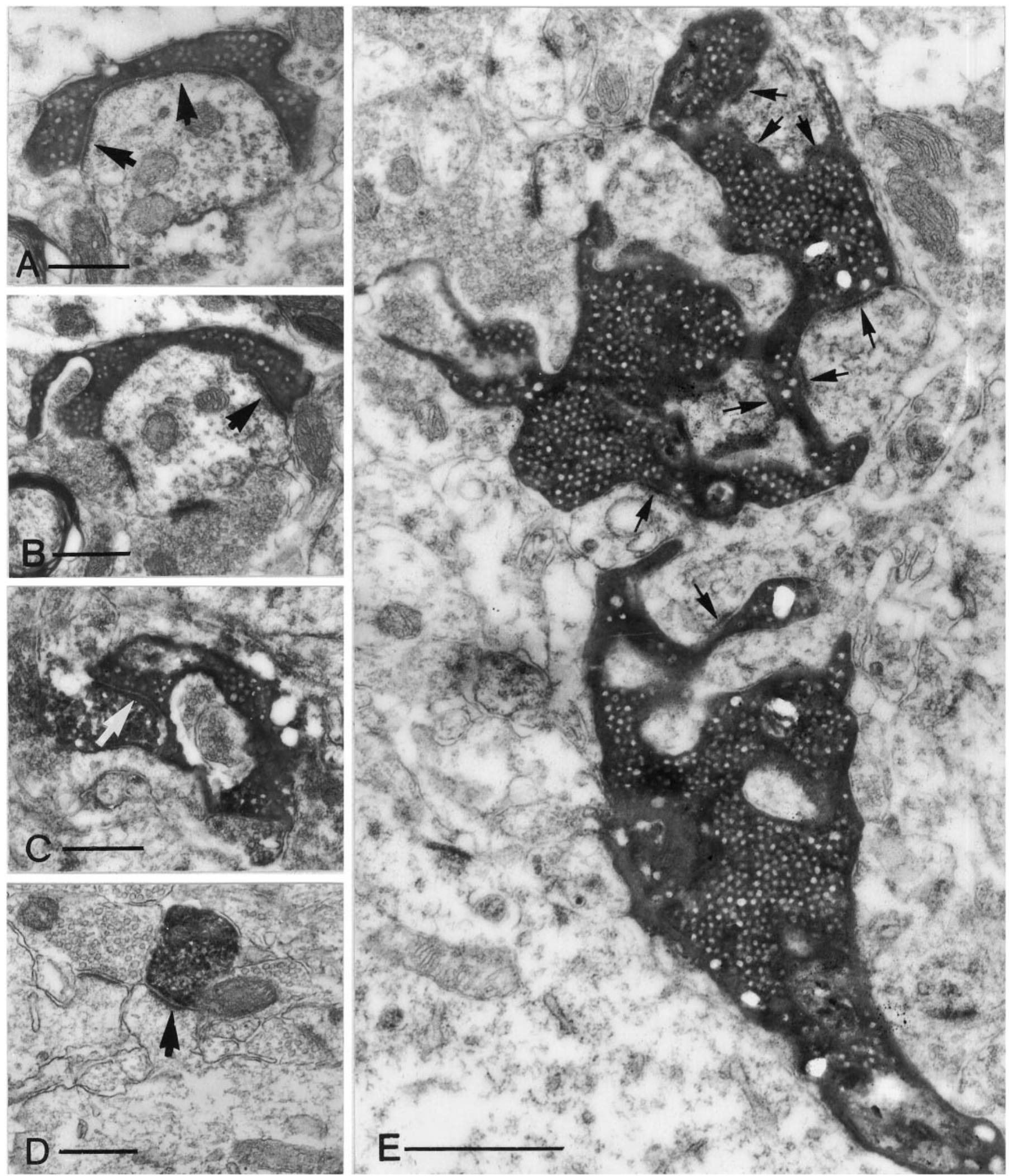

Figure 3. Electron micrographs of different terminal types along the mossy fibers in the CA3 region $(A-C, E)$ and of a CA3 pyramidal cell terminal $(D)$. All electron micrographs have the same magnification to help comparison of the relative size of the terminals. $A, B$, A small en passant terminal establishes a single asymmetrical synapse on a dendritic shaft with long perforated postsynaptic density (arrows). $C$, A filopodial extension of a mossy terminal forms a synapse (arrow) with an SPR-immunoreactive interneuron. $D$, The postsynaptic target of a pyramidal cell terminal is a simple spine of a CA1 pyramidal neuron. Compare this spine with the spines of GABAergic interneurons (Fig. 10). E, A large, double-headed mossy terminal forms multiple contacts (arrows) with thorny excrescences of a CA3 pyramidal cell. The individual release sites are short. Scale bars: $A-D, 0.5 \mu \mathrm{m} ; E, 1 \mu \mathrm{m}$. 
suggest that the divergence increases in the CA3c-CA3a axis, provided that the density of pyramidal cells in the different subregions is similar (Fig. 2C).

The electron microscopic appearance of mossy terminals (Fig. $3 E$ ) was similar to that described previously (Blackstad and Kjaerheim, 1961; Amaral and Dent, 1981; Chicurel and Harris, 1992). They were packed with a large number of round vesicles and a small number of dense core vesicles and formed intricate multiple asymmetric synaptic contacts with the thorny excrescences of pyramidal cells, which were embedded in the body of the terminal. In a fully reconstructed mossy terminal from 41 ultrathin sections, we found 31 synapses. The lengths of the individual postsynaptic densities were short. Mossy terminals also contacted the proximal apical shaft of the pyramidal cell with rows of punctum adherens-like specializations (Amaral, 1979). Previous research indicated that a single mossy terminal innervates thorny excrescences pertaining to the same pyramidal cell (Chicurel and Harris, 1992). Because double-headed mossy terminals were also encountered, we examined their postsynaptic targets. Two double-headed boutons were reconstructed from 41 and 54 serial electron microscopic sections, respectively (the second reconstruction was still partial). In both cases, both heads of the mossy terminals converged to thorny excrescences of the same pyramidal cell (Fig. 3E).

Filopodial extensions of the mossy terminals have been described previously in Golgi material (Amaral, 1979). In our study, many mossy terminals had varying numbers of hair-like extensions, often with bulbous endings (Figs. 1-3; see Figs. 4-6). The mean number of filopodial extensions with a bulbous ending $(2.25 /$ mossy terminal; $n=171)$ indicated that an average granule cell has 25-35 filopodial extensions. Electron microscopic examination of 15 filopodial extensions with a bulbous ending showed that all of them established synapses. The varicosities of filopodial terminals were packed with round vesicles and, in most cases, made only one synaptic specialization, often of the perforated type (Fig. 3). The postsynaptic densities were longer than those of the individual synapses of the mossy terminals or the terminals of CA3 pyramidal cells (Fig. 3; see Figs. 5, 6). The terminals also contained dense-core vesicles. Filopodial extensions did not form punctum adherens-like specializations even when unfilled terminals were examined (see below). The necks of the filopodia (2-50 $\mu \mathrm{m}$ long) were very thin, followed a tortuous route, and did not form synapses.

The terminals belonging to the third type were small en passant boutons along the mossy fibers (Fig. 3; see Fig. 6), as also seen in earlier studies (Gulyás et al., 1992; Soriano and Frotscher, 1993). These en passant varicosities were much smaller $(0.5-1.5 \mu \mathrm{m})$ than the mossy terminals. At the light microscopic level they appeared as a fusiform thickening of the main axon. The incidence of varicosities showed great variation among individual granule cells. To determine whether all of these varicosities represented conventional synapses, long segments of mossy fibers (total of $750 \mu \mathrm{m}$ in the CA3b region) were re-embedded and serially sectioned for electron microscopic reconstruction. The labeled mossy fibers were found embedded in the bundles of unstained mossy fibers. The electron microscopic examination revealed that many of the small varicosities were clumps of mitochondria or filling artifacts, and only a portion of them represented synapses. Serial reconstruction revealed that the average interval between en passant synaptic terminals was $250 \mu \mathrm{m}$, thus comparable to the distances of the large mossy terminals. Therefore, a single granule cell may give rise to $\sim 12-17$ small en passant synaptic terminals in the CA3 region. This figure should be considered an underestimation because the dark biocytin immunoprecipitate of the well filled main axon probably masked some synapses associated with the preterminal axon segment (Gulyás et al., 1992; Soriano and Frotscher, 1993). The ultrastructure of the small varicosities was similar to the bulbous endings of the filopodial extensions. The terminals were packed with round vesicles and formed mostly simple but occasionally perforated synapses with long postsynaptic thickenings. One of them, reconstructed from 15 ultrathin sections, showed that all postsynaptic specializations are indeed linked and form one long perforated synapse (Fig. $3 A, B$ ). The en passant synapses did not have punctum adherens-like specialization. Dense-core vesicles were also present in this terminal type.

\section{Target specificity of different mossy fiber terminals in the $\mathrm{CA} 3$ region}

Various neurochemical markers known to label distinct GABAergic neuron populations were used to examine the postsynaptic targets of the different terminal types. Substance P receptor (SPR) antibody was selected as a marker because it visualizes most GABAergic interneurons of various subtypes in the CA3 region in their entirety, including their distal dendrites and spines (Acsády et al., 1997). Other markers used in this study included parvalbumin, which labels a well characterized perisomatic inhibitory cell population, and calretinin, which is present in interneurons specialized to innervate other interneurons (Gulyás et al., 1996).

As discussed above, mossy terminals contacted the proximal dendrites of CA3 pyramidal neurons. Interneurons, however, were rarely among their postsynaptic elements. After systematic screening of 24 mossy terminals belonging to four granule cells, only one was found to form a putative contact with an SPRimmunoreactive cell (Fig. 4A). Correlated electron microscopy of this contact revealed that the mossy terminal made a conventional asymmetrical contact with a spine of an SPR-immunoreactive neuron.

In contrast, filopodial extensions of the large mossy terminals and small en passant terminals were often found to be in close apposition to SPR-immunoreactive neurons. Of 74 small terminals examined along the same mossy fibers at the light microscopic level, 35 made putative contacts on SPR-positive cells (Fig. $4 B)$. This figure is probably an underestimation because contacts on distal dendrites and especially on spines were often hard to discern. In these experiments several of the postsynaptic SPRpositive cells were reconstructed by camera lucida to examine the number of synaptic contacts on single cells from a single mossy fiber and to identify the target neuron types. A single mossy terminal often emitted several filopodial extensions. These extensions typically innervated different SPR-immunoreactive neurons with only a single contact. Multiple contacts (two to three) were encountered in only four cases. Correlated electron microscopy was performed in 21 cases (including one of the multiple contacts). Of the putative contacts, 18 of 21 were verified to form conventional asymmetric synapses (Figs. 5, 6). All postsynaptic targets that were examined showed the characteristics of interneurons, including invaginated nuclei, numerous mitochondria and other cytoplasmic organelles in the cell body, and a large number of asymmetrical synapses along the dendrites. The ultrastructure of SPR-immunoreactive spines showed pronounced differences from both the simple spines and the thorny excrescences of the pyramidal cells (Gulyás et al., 1992). Dendritic spines of interneurons were long and thin (up to $5 \mu \mathrm{m}$ ) and had no separate 




A



Figure 4. GABAergic interneurons are innervated by small terminals. Mossy fibers of two adjacent granule cells in CA3c. $A$, Large mossy terminals only exceptionally innervate SPR-immunoreactive neurons (arrow). B, Thirteen other SPR-immunoreactive interneurons (only 7 shown here) were contacted by either filopodial extensions or en passant terminals of the same two mossy fibers shown in $A$. Twelve of the 13 contacts were verified by electron microscopy (shown in Figs. 5, 6). All subtypes of SPR-immunoreactive cells were innervated by mossy fibers. The postsynaptic structures were somata (neurons 4 and 5) or proximal ( 1 and 7 ) or distal dendrites (2,3, and 6$)$. All contacts were single. Inset in $A$ shows the position of the reconstructed fibers in the CA3c subregion. Scale bar, $50 \mu \mathrm{m}$. str.luc., Stratum lucidum; str.pyr., stratum pyramidale; str.gran., stratum granulare. 
head region. The entire spine was covered with several asymmetrical synapses (see Fig. 10), in contrast to spines of pyramidal cells, which had a simple short neck and a mushroom-shaped head with usually a single synapse. Thorny excrescences of pyramidal cells, embedded in the large mossy terminals, were also easily distinguishable. Interneuron spines were not embedded in the large mossy boutons.

Every type of SPR-positive interneuron was represented among the postsynaptic targets of filopodial extensions and small terminals (Fig. 4B). Spiny SPR-positive neurons (Acsády et al., 1997), with dendrites parallel to the mossy fibers, were innervated more frequently. The postsynaptic structures included somata, proximal or distal dendritic shafts, and spines. Given the restricted course of granule cell axons, the location of synapses depended primarily on the type of structure present in the stratum lucidum without any preference for somata, proximal, or distal dendrites.

To determine whether filopodial extensions establish synaptic contacts with pyramidal neurons, the postsynaptic targets of four filopodia, which did not contact SPR-immunoreactive elements, were examined under the electron microscope. All four terminals innervated distal dendrites with ultrastructural characteristics of GABAergic cells, which were clearly distinguishable from the thick primary dendrites and thorny excrescences of pyramidal cells in stratum lucidum. Furthermore, examination in serial ultrathin sections of the 18 terminals that established synapses on the SPR-positive cells revealed only single release sites on the SPR-positive interneurons. No additional release sites were found for potential contacts with the surrounding pyramidal cells.

Convergence of granule cells on interneurons was examined in one case in which two adjacent granule cells were intracellularly labeled. From the 18 SPR-immunoreactive neurons innervated by the filopodial extensions and small en passant terminals of the two granule cells, one spiny SPR-positive cell was found to receive synaptic contacts from both granule cells (Fig. 6).

Analysis of parvalbumin- and calretinin-immunoreactive postsynaptic targets of the various terminal types confirmed and extended the above observations that interneurons were innervated by filopodial extensions and small en passant terminals (Fig. $6 G, H)$. A segment of a parvalbumin-immunoreactive dendrite in the stratum lucidum was reconstructed from 45 electron microscopic sections, and all afferent synaptic boutons were photographed. In addition to the single synapse established by the biocytin-labeled terminal, 19 unlabeled boutons forming asymmetrical synapses were identified. All of these showed ultrastructural characteristics of small terminals. Their diameter was $<1.5$ $\mu \mathrm{m}$, and they formed single, usually perforated synapses with long postsynaptic thickening. Puncta adherentia were not present. Many of the small terminals contained dense-core vesicles, indicating granule cell origin. These observations support the suggestion that excitatory inputs of granule cells to CA3 interneurons are established by small en passant or filopodial terminals and not by large mossy boutons.

To summarize, our analysis of postsynaptic targets of granule cells in the CA3 region indicates that (1) mossy terminals innervate pyramidal cells, whereas filopodial extensions and small en passant terminals contact primarily interneurons, and (2) small terminals and filopodial extensions outnumber mossy terminals; therefore granule cells innervate substantially more GABAergic interneurons than pyramidal cells.

\section{Terminal types of granule cells in the hilar area}

Nearly the entire local axon arbor of the labeled granule cells was within the border of the hilar region as visualized by SPR and mGluR1a immunostaining ( $p=6$ cells) (see below), confirming previous Golgi and single cell labeling studies (Ramón y Cajal, 1911; Claiborne et al., 1986). The main axon of the granule cell emitted five to eight thinner side branches in the hilus, which occasionally bifurcated and gave rise to secondary branches. The side branches followed a tortuous route usually parallel to stratum granulosum. A recurrent collateral penetrating into stratum granulosum was observed only in a single case. The total septotemporal extension of the hilar plexus was $600 \mu \mathrm{m}$. However, 90\% of the hilar collaterals was within a $400 \mu \mathrm{m}$ lamella. The transversal extent of the hilar axon arbor depended on the location of the soma and varied from 400 to $700 \mu \mathrm{m}$.

The terminal types in the hilus were similar to those described in the CA3 region (Fig. 7). However, small terminals along the side branches were much more numerous than in area CA3. Many of the small terminals were situated on a short stalk and formed "drumstick" rather than en passant boutons. Each side branch had one or two large mossy terminals and associated filopodial extensions. Not all mossy boutons were in the terminal position. A single granule cell had 7-12 mossy boutons and 102-147 small terminals ( $p=5$ cells). Correlated light and electron microscopy of 26 terminals verified synapse in each case. Thus, artifactual en passant varicosities, observed in the CA3 region, were much less common in the hilar area. The intervals between small terminals were highly variable.

The ultrastructural features of small terminals and filopodial extensions were identical to those described above for the terminals in the CA3 region. In addition, 5-10\% of the terminals showed characteristics intermediate between the large mossy and small terminals. These latter varicosities had a diameter of 2-3 $\mu \mathrm{m}$, displayed multiple release sites, and occasionally innervated a GABAergic cell and the distal dendrite of a putative mossy cell at the same time (Fig. $7 D, E$ ). These intermediate-size terminals therefore might be considered a variant of the mossy terminal.

\section{Postsynaptic interneuron targets of the granule cells in the hilus}

SPR and mGluR1a immunostaining were used to study the postsynaptic targets of granule cells. These antibodies were chosen because they label a large fraction of GABAergic interneurons in the hilar region and because the dendritic distribution of these cells clearly outlines the border between the hilus and the CA3c region (Ramón y Cajal, 1911; Amaral, 1978), as indicated by two independent means. First, the distal dendrites of in vivo filled CA3c pyramidal cells always terminated outside the border of the densely immunoreactive area. Second, all dendrites of an in vivo filled mossy cell were confined to the hilar region, as outlined by SPR staining.

The postsynaptic interneuron targets of granule cells in the hilus were examined by using antibodies against mGluR1a ( $p=$ 2 cells) and SPR ( $n=4$ cells). mGluR1a immunoreactivity is present in all somatostatin-positive interneurons (Baude et al., 1993), whereas $60 \%$ of somatostatin-immunoreactive cells also contain SPR (Acsády et al., 1997). In addition, SPR is present in other GABAergic cell types (Acsády et al., 1997). Thus, the two markers label partially overlapping sets of GABAergic interneurons in the hilus. All mGluR1a-immunoreactive neurons had large fusiform or polygonal cell bodies and three to five primary dendrites, which were densely covered with long spines that had 

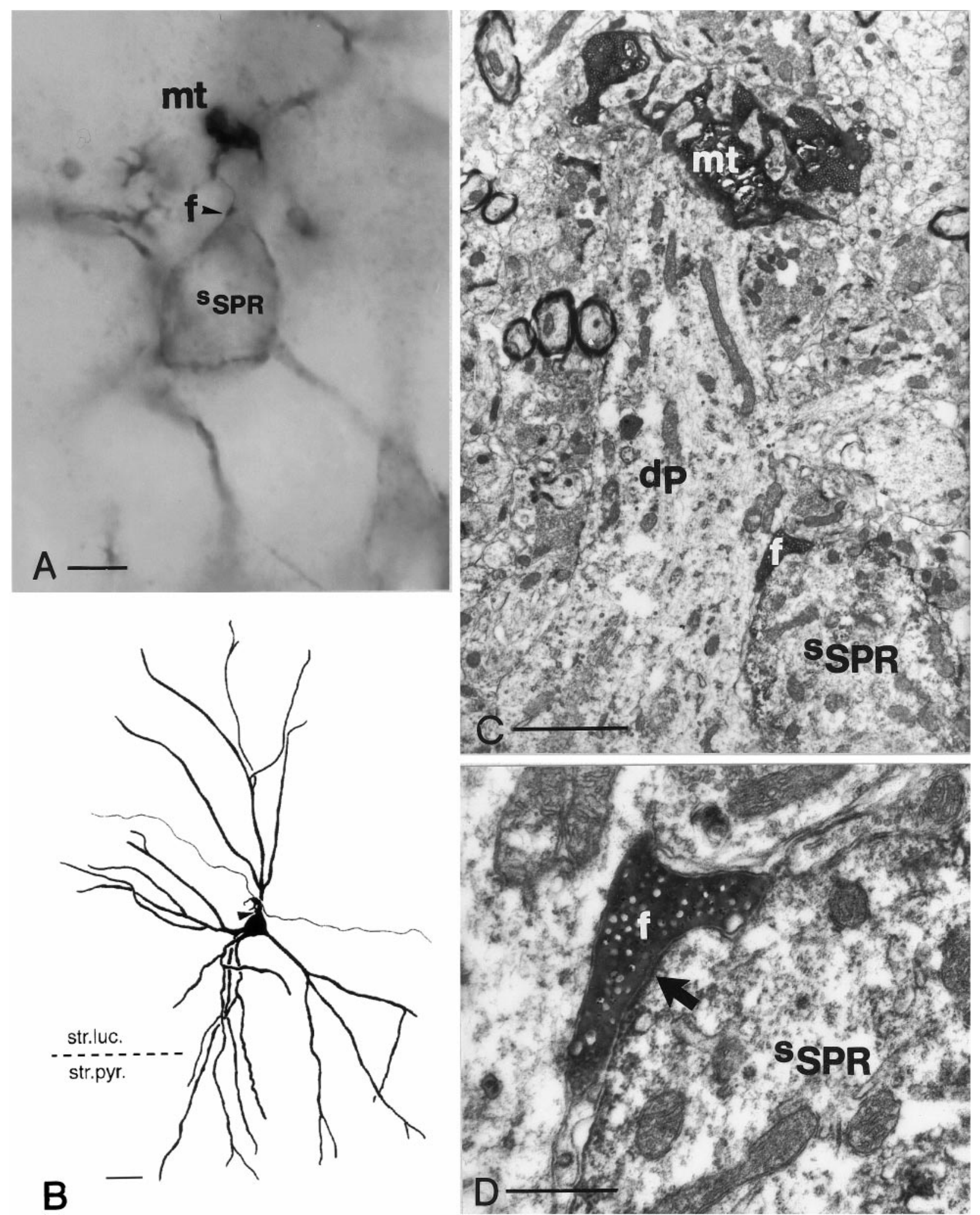

Figure 5. Correlated light and electron micrographs of a contact between a filopodial extension and an SPR-positive interneuron. $A$, High-power light micrograph of an intracellularly labeled mossy terminal $(\mathrm{mt}$ ) showing one of its filopodial extensions (arrowhead, $f$ ) in close apposition to an SPR-positive interneuron $\left(s_{S P R}\right)$ in the CA3c region. $B$, Camera lucida reconstruction of the contacted SPR-containing cell, together with the afferent mossy fiber segment (neuron 4 in Fig. 4). $C$, Low-power electron micrograph. Note that the mossy terminal (mt) contacts the thorny excrescenses of a pyramidal cell dendrite $\left(d_{P}\right)$, whereas the terminal bulb of the filopodium $(f)$ is attached to the soma of the SPR-positive interneuron $\left(s_{S P R}\right)$. $D$, High-power electron micrograph of the asymmetrical synapse (arrow) established by the filopodium $(f)$ on the soma of the SPR-containing interneuron $\left(s_{S P R}\right)$. Scale bars: $B$, $25 \mu \mathrm{m} ; C, 1 \mu \mathrm{m} ; D, 0.5 \mu \mathrm{m}$. 

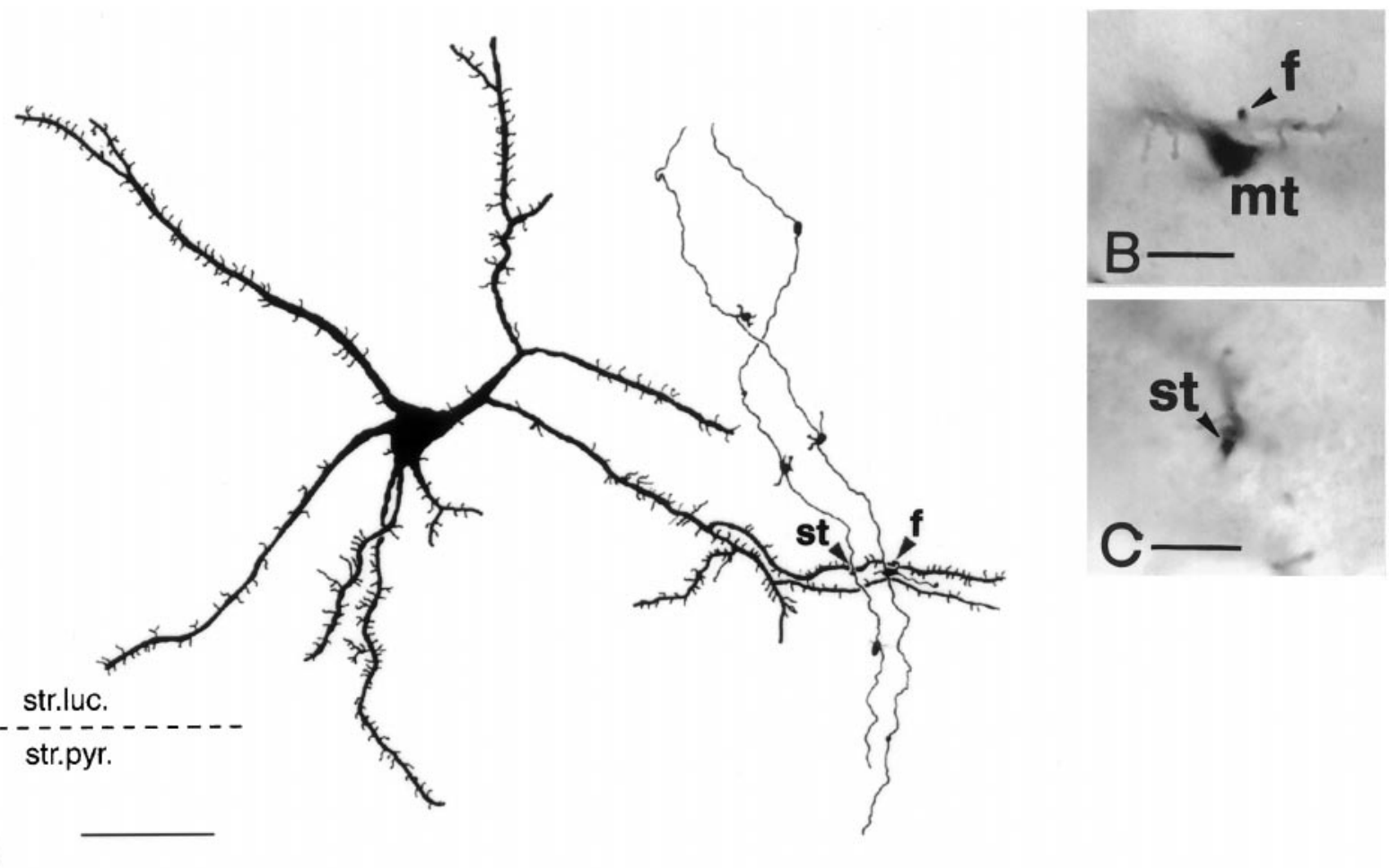

A
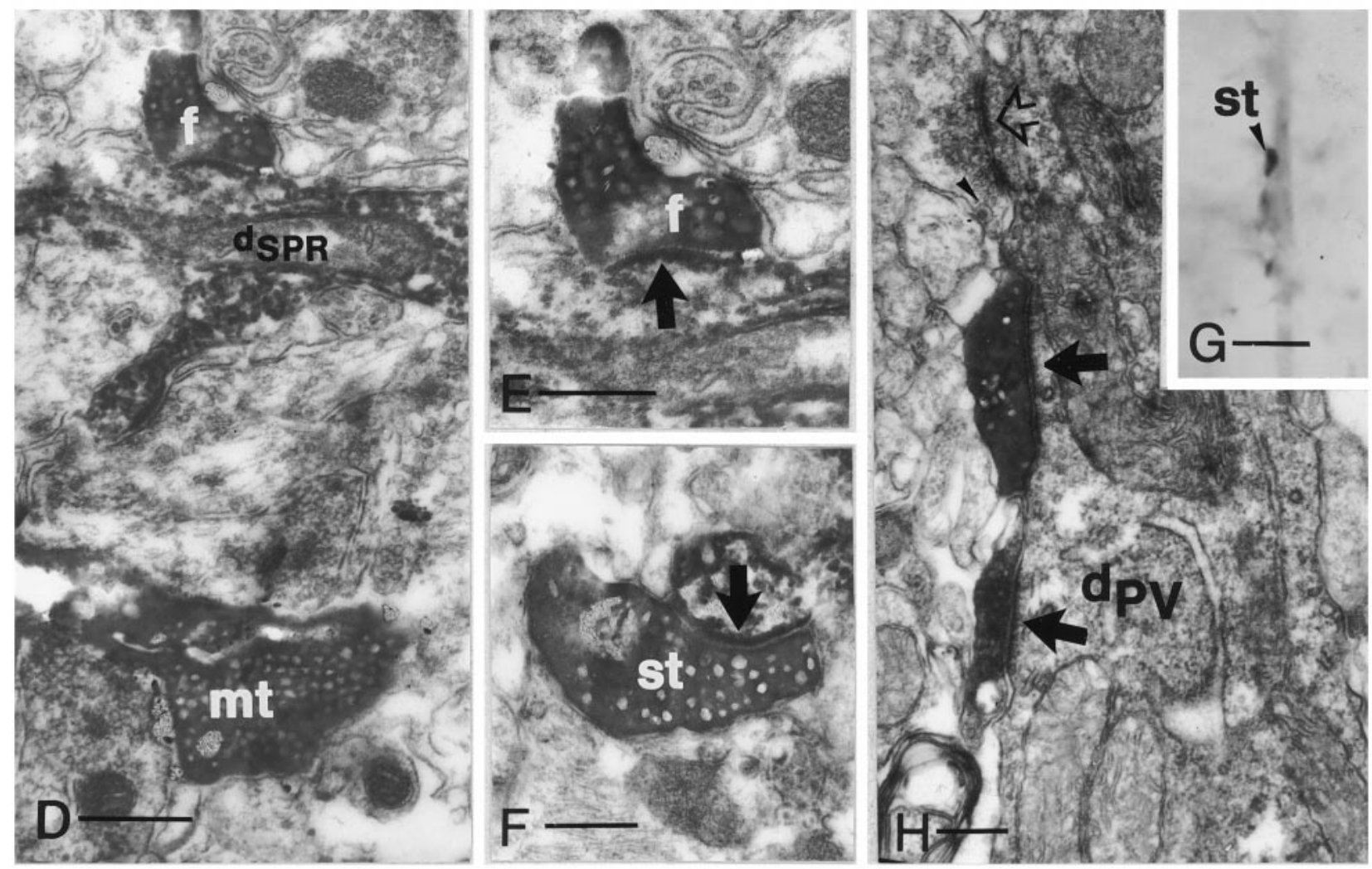

Figure 6. Convergence of adjacent granule cells to a spiny SPR-immunoreactive cell $(A-F)$ and innervation of a parvalbumin-positive interneuron by a granule cell $(G-H)$. $A$, Camera lucida drawing of an SPR-positive spiny neuron in the CA3c subregion (neuron 3 in Fig. $4 B$ ). The same tertiary dendrite is contacted by mossy fibers of two neighboring granule cells (arrowheads). The left contact is formed by a small en passant terminal (st), whereas the right contact is formed by a filopodial extension $(f) . B, C$, High-power light micrographs of the mossy terminal (mt), terminal bulb of the filopodial extension (arrowhead, $f$ in $B$ ), and the small en passant terminal (arrowhead, st in $C$ ). $D-F$, Correlated electron micrographs of mossy terminal (mt), filopodia $(f)$, and small terminal (st), respectively. Arrows indicate synapses. G, High-power light micrograph of a small en passant terminal in close apposition to a parvalbumin-positive dendrite (arrowhead). H. Electron micrograph showing two separate release sites (arrows), a rare case for small terminals. Open arrow indicates unlabeled small terminal; arrowhead indicates dense-core vesicle. $d_{P V}$, Parvalbumin-positive dendrite Scale bars: $A$, 50 $\mu \mathrm{m} ; B, C, G, 10 \mu \mathrm{m} ; D, 1 \mu \mathrm{m} ; E, F, 0.3 \mu \mathrm{m} ; H, 0.5 \mu \mathrm{m}$. 

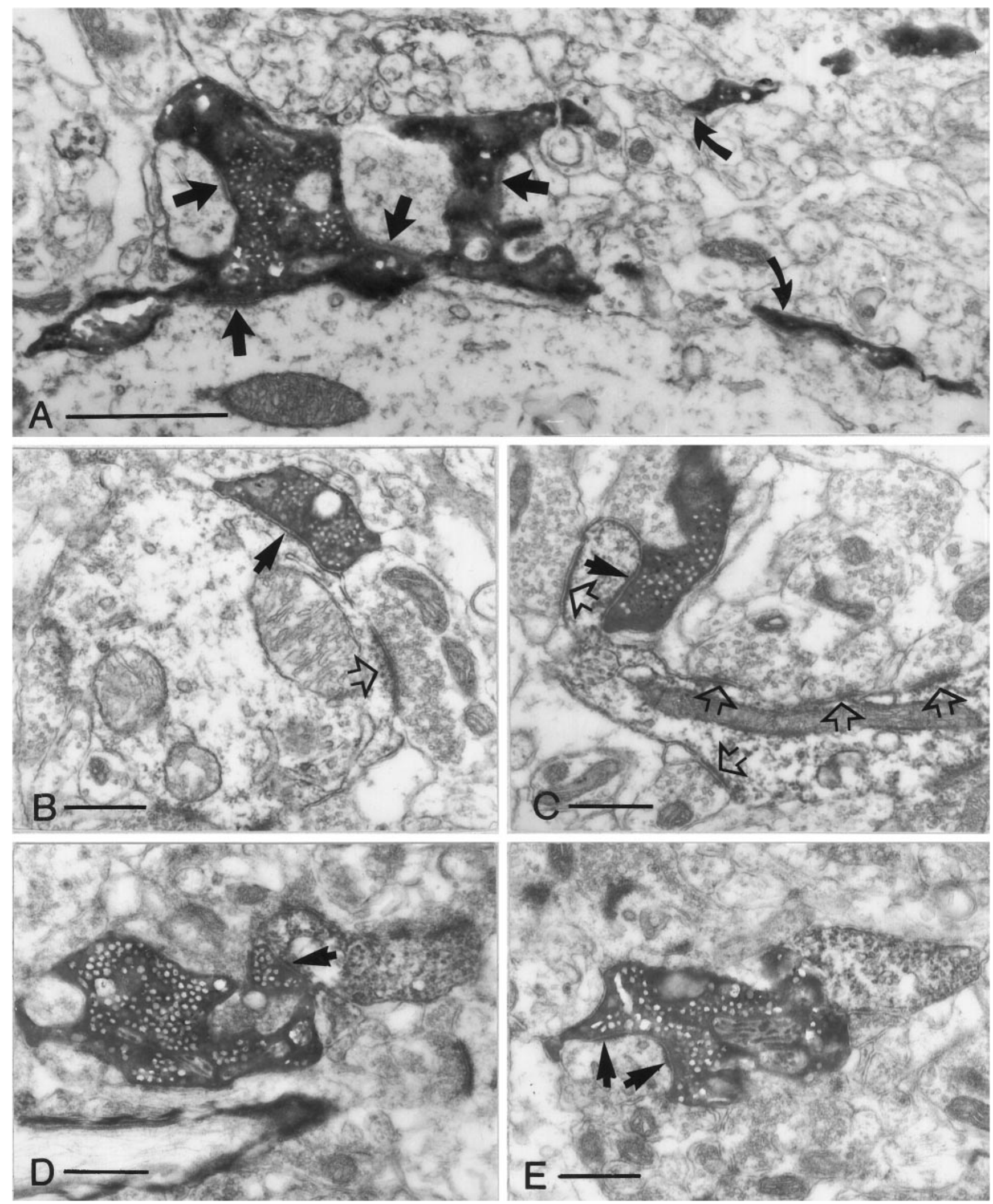

Figure 7. Terminal types of mossy fibers in the hilus. All electron micrographs have the same magnification. A, Mossy terminal establishing four synapses (arrows) with the shaft and the thorny excrescences of a mossy cell. Curved arrows point to the filopodiae originating from this terminal. $B$, A small en passant terminal with single release site (arrow) contacts a dendritic shaft. $C$, A drumstick-like small terminal forms a synapse on the proximal part of an SPR-positive spine. Open arrows in $B$ and $C$ label synapses formed by unlabeled small terminals. $D, E$, Intermediate terminal type contacting a distal SPR-positive dendritic shaft (arrow in $D$ ) and on a neighboring section forming two synapses (arrows in $E$ ) on a putative mossy cell. Scale bars: $A, 1 \mu \mathrm{m} ; B-E, 0.5 \mu \mathrm{m}$. 


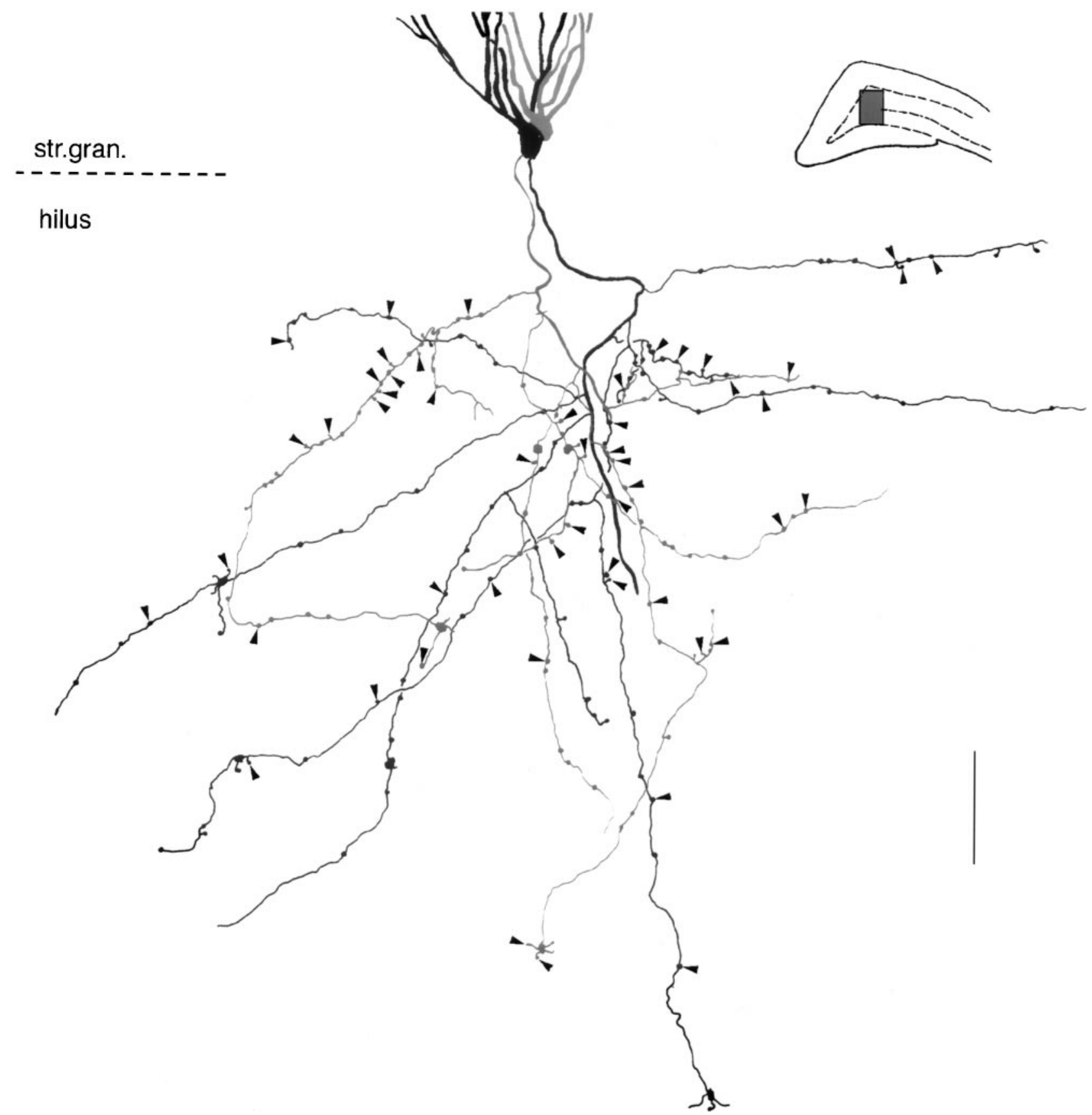

Figure 8. GABAergic cells are major postsynaptic targets of the small terminals of granule cells in the hilus. Shown are hilar axon arbors of two adjacent granule cells ( gray and black) and their mGluR1a-immunoreactive targets reconstructed from three neighboring $60-\mu \mathrm{m}$-thick sections. Fifty-two of the 175 small terminals and filopodiae (arrowheads) innervated mGluR1a-immunoreactive targets, whereas large mossy terminals contacted none. A representative sample of 22 contacts was identified at the EM level (illustrated in Fig. 10). Boxed area in the inset shows the position of the axon arbor. Scale bar, $50 \mu \mathrm{m}$.

many branches. SPR immunostaining labeled GABAergic neurons similar to those in the $\mathrm{CA} 3$ region.

The large mossy terminals did not contact mGluR1a-positive cells $(n=11)$. In contrast, 52 of the 175 small terminals and filopodiae that were examined $(30 \%)$ innervated mGluR1aimmunoreactive neurons (Fig. 8). A representative sample of 22 contacts was identified by correlated light and electron microscopy as a conventional asymmetrical synapse (Fig. 10). The postsynaptic targets of four granule cells were examined with SPR immunostaining. Of the small terminals examined, 44 of the 76 $(58 \%)$ were in close apposition to SPR-immunoreactive somata, dendrites, or spines. Four of these contacts were examined at the electron microscopic level, and a single synapse was verified in each case. The higher ratio of contacts in the case of SPR-positive cells may reflect the higher percentage of interneurons labeled by this marker in the hilar region. None of the markers used alone or in combination label all hilar GABAergic cells. Nevertheless, the high incidence of synaptic contacts observed with these markers indicates that most of the small terminals innervate GABAergic cells in the hilar region.

To determine whether small en passant terminals had an absolute target selectivity for interneurons in the hilar region, presyn- 


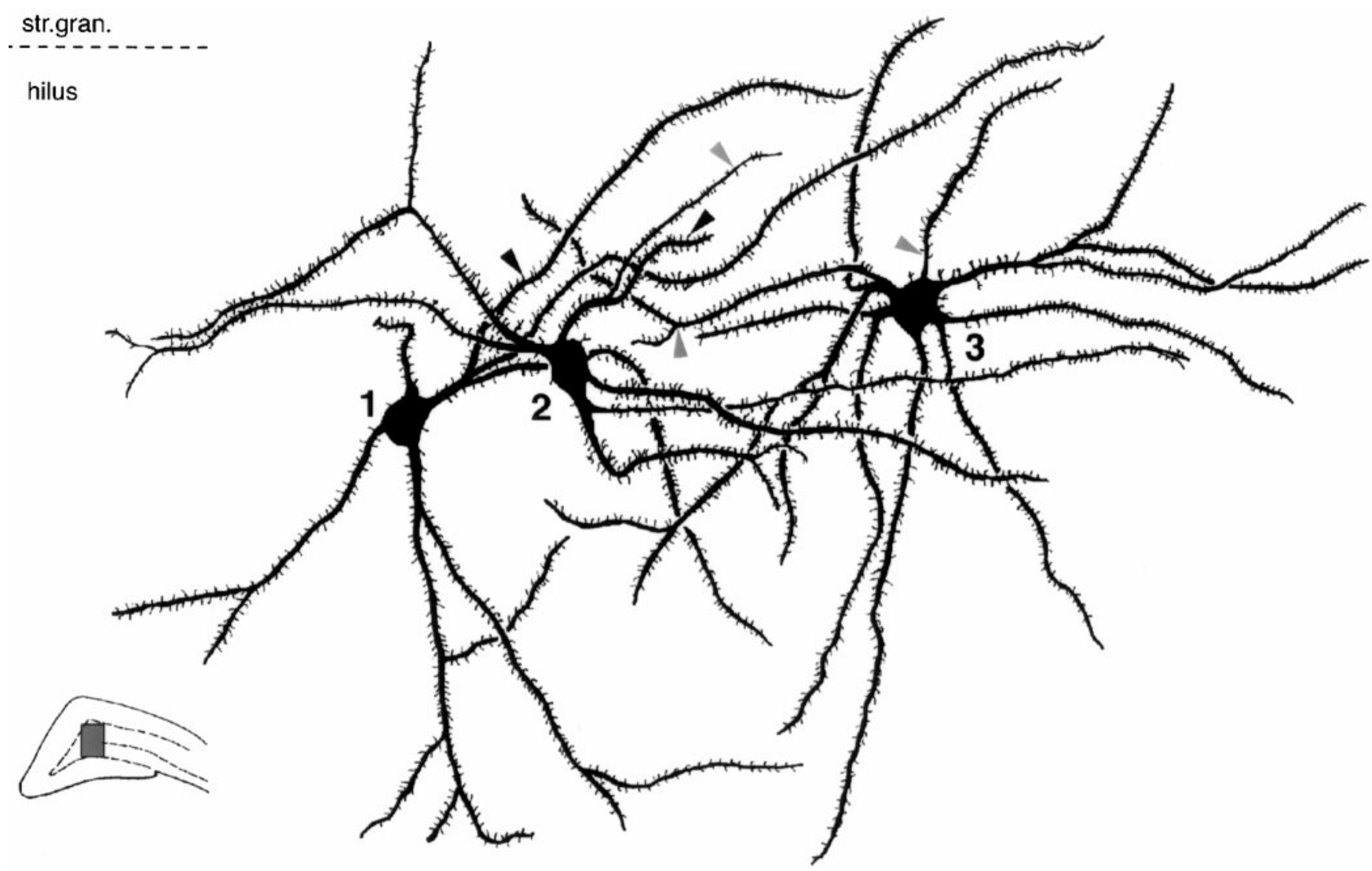

Figure 9. Convergence and divergence of granule cell contacts on hilar mGluR1a-positive neurons. Camera lucida reconstruction of three hilar mGluR1aimmunoreactive neurons from six $60-\mu \mathrm{m}$-thick sections, innervated by the two granule cells shown in Figure 8 . Neuron 1 received a single contact from one of the granule cells (black arrowhead); both granule cells converged onto neuron 2 with single contacts each (black and gray arrowhead), whereas neuron 3 was innervated by two terminals of the other granule cell ( gray arrowheads). Correlated electron micrographs of the contacts are shown in Figure 10.

aptic terminals impinging on the distal dendrites of an intracellularly filled mossy cell were examined. Several terminals that established synapses on distal dendritic shafts or spines of the mossy cell bore the characteristics of small terminals of granule cells (data not shown). This observation therefore indicates that small terminals in the hilar region also can be presynaptic to mossy cells. Nevertheless, the high ratio of contacts between the small terminals and GABAergic interneurons in the dorsal hilus suggests a target preference for interneurons.

The convergence and divergence of granule cells were studied with mGluR1a immunostaining in a rat in which two granule cells were labeled. The postsynaptic mGluR1a-immunoreactive neurons were reconstructed with camera lucida from seven consecutive $60-\mu \mathrm{m}$-thick sections with the highest density of axon collaterals (Fig. 9). The seven reconstructed mGluaR1a-immunoreactive neurons received 11 contacts, 6 of which were identified under the electron microscope. Two of the seven cells received convergent inputs from both granule cells. Most contacts corresponded to single release sites. Double contacts were found in two cases. These contacts were found on different dendritic branches in both cases (Fig. 9). Postsynaptic targets included somata, proximal or distal dendritic shafts, and spines (Fig. 10).

\section{Dynorphin-SPR double immunostaining}

Because mossy fibers contain the neuropeptide dynorphin (McLean et al., 1987; Drake et al., 1994), immunostaining against this neuropeptide allowed us to identify their terminals and investigate their postsynaptic elements using double immuno- staining against dynorphin and SPR (pre-embeding gold and DAB, respectively; see Materials and Methods). Dynorphin immunoreactivity was present in the mossy fiber system as a diff use precipitate, as described previously (McLean et al., 1987; Drake et al., 1994), but a few individual mossy terminals showed very strong immunoreactivity. At the ultrastructural level, gold particles indicated that dynorphin immunoreactivity was distributed in synaptic terminals with characteristics of both large and small terminal types (Fig. 11). In addition to axonal staining in the hilar region, weak immunoreactivity was present also in the dendrites of granule cells, as described previously (Drake et al., 1994). The pattern of SPR immunostaining remained unchanged after the pre-embedding gold staining procedure. Examination of 21 dynorphin-positive terminals, establishing asymmetrical synapses with SPR-positive profiles, demonstrated that all of them showed the characteristics of small terminal types (Fig. 11). The presynaptic terminals were $0.5-1.0 \mu \mathrm{m}$ in diameter, formed single release sites, and did not have punctum adherens-like specialization. These results confirmed that most excitatory input to GABAergic cells from granule cells derives from small terminals.

\section{DISCUSSION}

The main findings of the present study are that (1) granule cells innervate their principal cell and interneuron targets preferentially by large mossy boutons and small en passant or filopodial terminals, respectively; (2) they innervate substantially more inhibitory than excitatory cells; and (3) convergence of granule cells to principal 

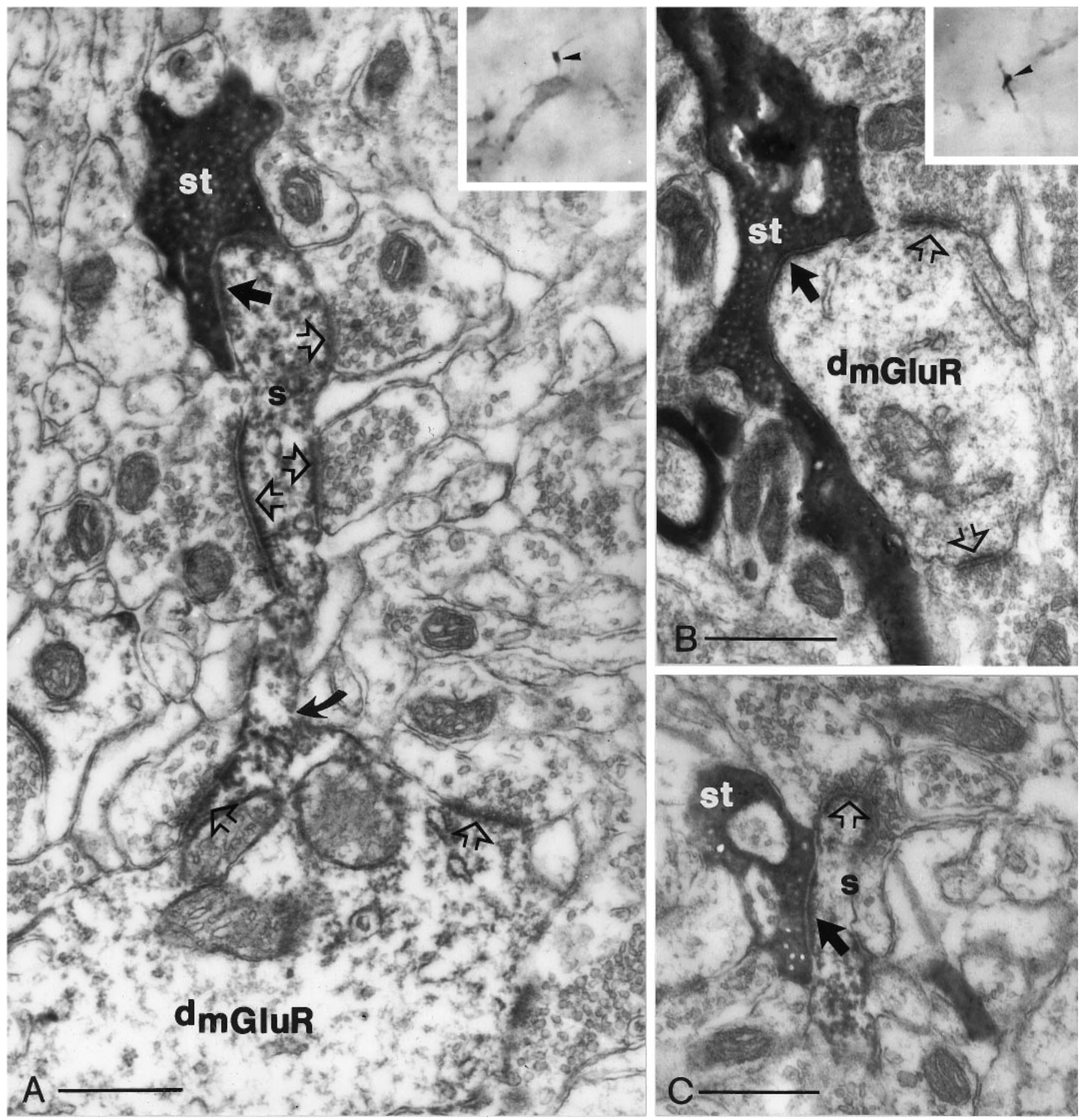

Figure 10. Small terminals of mossy fibers innervate mGluR1a-containing GABAergic cells $\left(d_{m G l u R}\right)$ in the hilus. Correlated light (small insets $)$ and electron micrographs of three contacts shown in Figure 9. Neurons 1 and 2 are contacted (arrows in $A$ and $C$, respectively) on their spines ( $s$ ), whereas neuron 3 receives a synapse on a proximal dendrite $(B)$. Open arrows label synapses formed by unlabeled small terminals. $s t$, Small terminal. Scale bars: $A-C, 0.5 \mu \mathrm{m}$.

cells is very limited, whereas convergence on interneurons may be high. At the cellular level, this synaptic arrangement may allow for the target-dependent regulation of glutamate release, whereas at the network level it may efficiently suppress recurrent excitation in the CA3 collaterals but allow for the selective discharge of a few CA3 pyramidal cells.

\section{Granule cells affect their targets by morphologically different terminals}

The present in vivo single cell labeling study confirms and extends previous works using Golgi material and the in vitro slice preparation regarding the topography of the mossy fiber system 


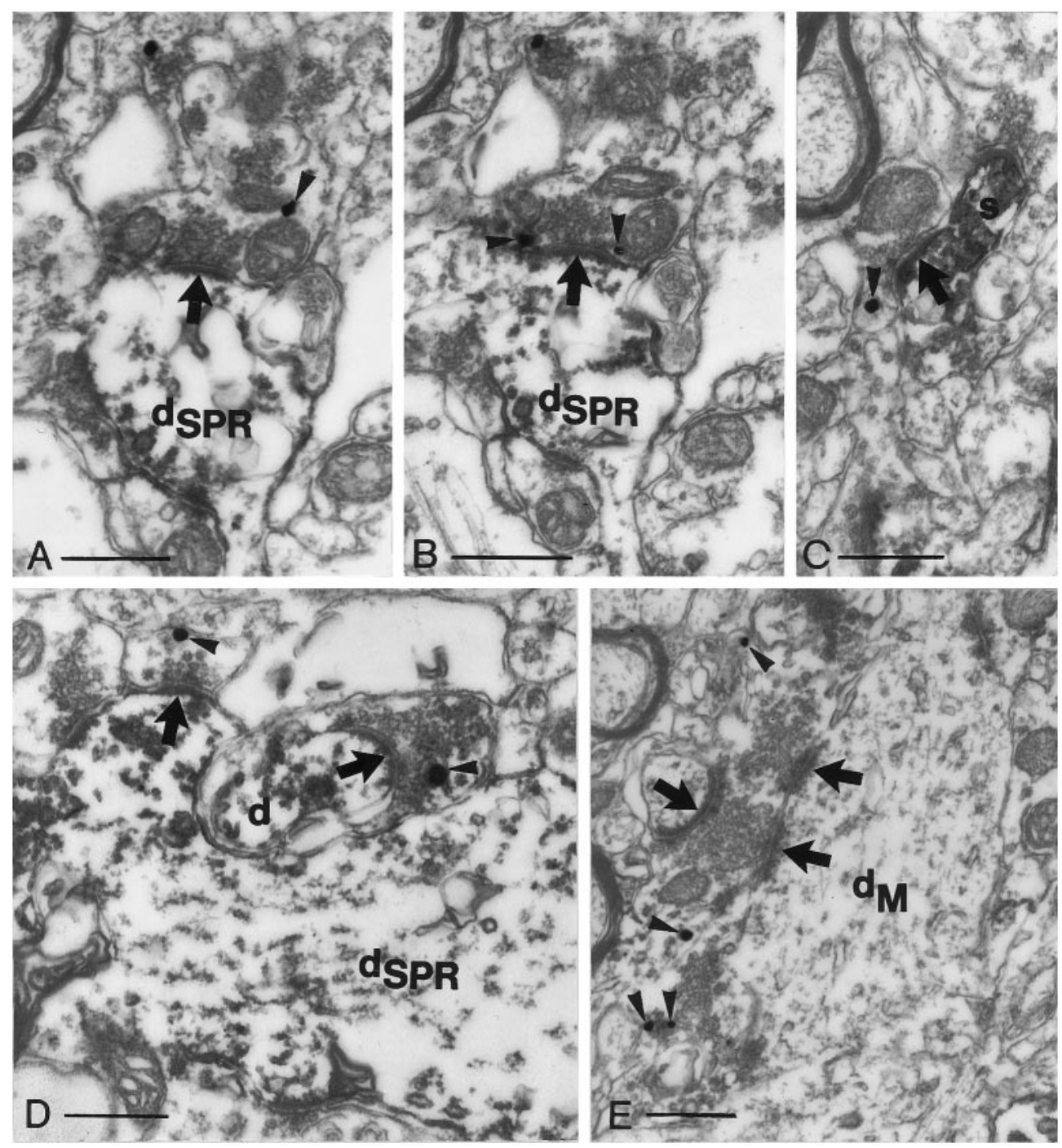

Figure 11. Excitatory inputs from granule cells to GABAergic cells are established by small terminals. Dynorphin (mossy fibers)-SPR (interneurons) double immunostaining. Dynorphin and SPR were visualized using preembedding gold immunostaining (dark, electron-dense particles labeled by $a r$ rowheads) and DAB (diffuse precipitate), respectively. $A, B$, Two neighboring sections show that a dynorphinpositive terminal contacts (arrows) a distal SPR-immunoreactive dendritic shaft $\left(d_{S P R}\right)$. Note that the presynaptic terminal shows the characteristics of small mossy fiber terminals (i.e., single, long postsynaptic thickening, lack of punctum adherens). $C, D$, The same type of terminals contact (arrows) an SPR-positive spine ( $s$ in $C$ ) and a proximal and a distal dendrite $\left(d_{S P R}\right.$ and $d$, respectively, in $D) . E, \mathrm{~A}$ large dynorphin-positive terminal forms multiple contacts on an SPR-negative mossy cell dendrite $\left(d_{M}\right)$. Scale bars: $A-E, 0.5 \mu \mathrm{m}$.

(Swanson et al., 1978; Amaral and Witter, 1989; Tamamaki and Nojyo, 1991). Local collaterals of a single granule cells in the dorsal hippocampus arborized in the hilus, whereas the main axon coursed in the CA3 region. Most hilar branches and the main axon in the CA3c and CA3b regions remained within a 400 $\mu \mathrm{m}$ transversal lamella. However, in the CA3a region the mossy terminal turned caudally and continued for up to $1 \mathrm{~mm}$. The intervals of mossy terminals increased in the CA3c to CA3a direction. This might reflect the lower packing density of pyramidal cells in the distal CA3 region or increasing divergence.

Cortical pyramidal cells give rise to large numbers of axon collaterals and innervate all postsynaptic targets with morphologically identical boutons (Kisvárday et al., 1986; Gulyás et al., 1993; Sík et al., 1993; Li et al., 1994). In contrast, granule cells have very specialized synaptic terminals, including the large mossy boutons, small en passant terminals, and filopodial extensions of the mossy boutons (Ramón y Cajal, 1911; Amaral, 1979; Claiborne et al., 1986). These three terminal types were observed in both the hilus and the CA3 region. Electron microscopic examination demonstrated ultrastructural similarities between filopodial extensions and the small en passant terminals and their differences from the large mossy boutons. The large mossy terminals had as many as 31 release sites, confirming previous results (Chicurel and Harris,
1992). In addition, they contacted the pyramidal cells by rows of puncta adherentia. In contrast, the small en passant terminals and filopodial extensions in most of the cases established a single release site and did not have punctum adherens-like specializations. A single granule cell gave rise to only 7-12 large mossy boutons in the hilus and 11-18 boutons in the CA3 region. In contrast, the number of small terminals (en passant and filopodial) was considerably higher both in the hilus $(120-150)$ and the CA3 region $(40-50)$. The number of small terminals is likely underestimated because of technical factors, including incomplete filling of thin filopodial extensions and biocytin "masking" of en passant terminals.

\section{Large mossy boutons and small terminals preferentially innervate principal cells and interneurons, respectively}

Cortical pyramidal neurons innervate their postsynaptic principal and interneuron targets nonpreferentially, i.e., the incidence of the targets is determined by the relative distribution of the neuron types (Kisvárday et al., 1986; Gulyás et al., 1993; Sík et al., 1993). Our findings indicate that this is not the case with granule cells. The GABAergic targets were preferentially innervated by filopodial extensions and the small en passant terminals and only 
exceptionally by the large mossy bouton. Some previous observations are in accordance with this conclusion (Amaral, 1978, his Figs. 46, 75; Ribak and Seress, 1983, their Fig. 16; Gulyás et al., 1992; Ribak, 1992; Soriano and Frotscher, 1993; Halasy and Somogyi, 1993; Geiger et al., 1997). Two previous electron microscopic studies indicated that the postsynaptic targets of small terminals were smooth dendrites, a known characteristics of several GABAergic cell types (Amaral, 1979; Claiborne et al., 1986). In contrast, other studies suggested that the large mossy terminals contact GABAergic cells both in the hilus and in the CA3 region of the rat (Frotscher, 1985; Ribak and Seress, 1988; Frotscher, 1989; Deller and Léránth, 1990; Léránth et al., 1990; Nitsch et al., 1990; Deller et al., 1994) and the monkey (Seress and Léránth, 1996). This apparent controversy is likely attributable to the difficulty involved in the identification of postsynaptic targets at the light microscopic level and the lack of a reliable marker of presynaptic terminals in most of these studies. Importantly, none of these investigations attempted to quantitatively assess the regional distribution of the different terminal types and their precise neuronal targets.

Several observations in our study suggest that small terminal types form the majority of synaptic contacts between granule cells and interneurons. First, examination of the intracellularly filled granule cells showed that a large portion of their targets were GABAergic, as indicated by the SPR, mGluR1a, calretinin, or parvalbumin immunoreactivity of the innervated neurons. In the CA3 region, $47 \%$ of the small terminals contacted SPRcontaining cells, although SPR-immunoreactive neurons make up $<5 \%$ of the total neuronal population in this region. In the hilus, 30 and $58 \%$ of small terminals innervated mGluR1a- and SPRimmunoreactive cells, respectively, which better matches the proportion of these interneurons within the GABAergic population rather than within the entire neuron population of the hilus. Clearly, not all GABAergic cells were labeled by these markers. Most contacts made by a single granule cell with its interneuron targets corresponded to a single release site. Second, we found no indication that dendrites of pyramidal cells were contacted by either the small en passant boutons or the filopodial extensions, although in the hilar region, small terminals of assumed granule cells innervated the distal dendrites of mossy cells. Third, electron microscopic examination revealed that dynorphin-immunostained presynaptic terminals on GABAergic dendrites in the hilus and the CA3 region were always of small size $(0.5-2.0 \mu \mathrm{m})$.

GABAergic cells form a morphologically and functionally diverse neuronal population (Freund and Buzsáki, 1996). All GABAergic subgroups examined with antibodies against SPR, mGluR1a, parvalbumin, and calretinin were innervated by the small terminals of granule cells. Spiny GABAergic cells with horizontal dendrites in the stratum lucidum and their hilar counterparts, visualized with mGluR1a and SPR and calretinin immunostainings, were innervated more frequently than the other morphological categories. This may be because their dendrites are restricted to the termination zone of mossy fibers and because their dendritic surface is increased several-fold by a large number of spines. These spiny cells also colocalize somatostatin and NPY (Baude et al., 1993; Acsády et al., 1997), and their axons innervate the distal dendritic region of principal cells, in association with the entorhinal afferents (Han et al., 1993; Deller and Léránth, 1990; Léránth et al., 1990; Sík et al., 1997). This inhibitory feed-back loop therefore may exert an effective control on the entorhinal activation of granule cells.

The large mossy terminals contacted pyramidal cells and mossy

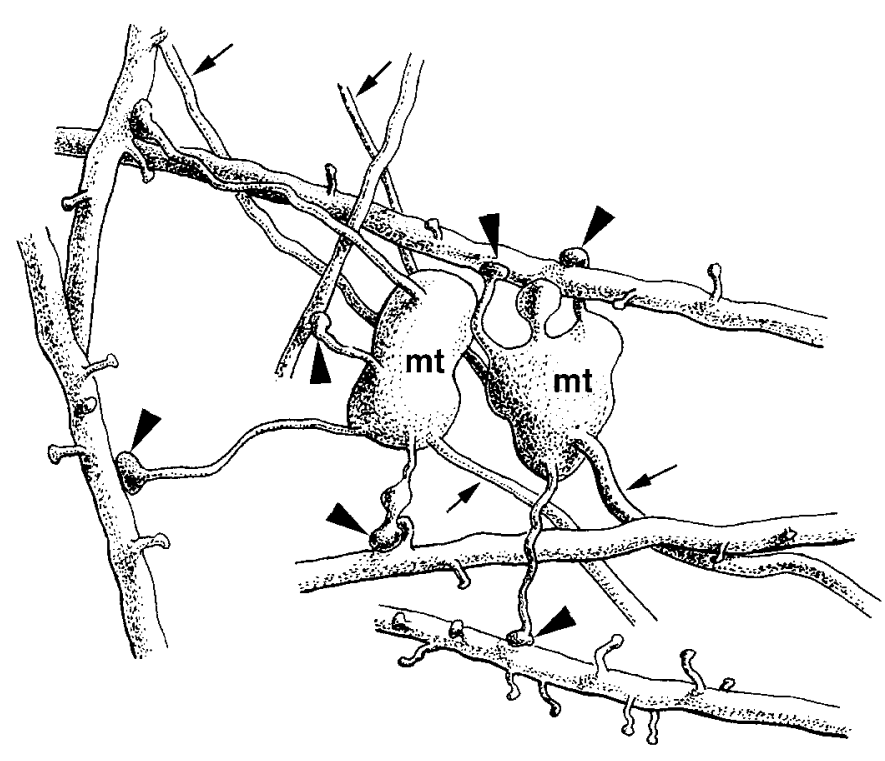

Figure 12. Filopodial extensions of mossy terminals are specialized to innervate GABAergic cells. Artistic rendition of two mossy terminals, each with four filopodial extensions (large arrowheads). All filopodial terminals contacted the dendrites or spines of six GABAergic neurons. Four of them were identified by their SPR-content and two of them by ultrastructural characteristics. Five of the six postsynaptic interneurons were spiny cells. All synapses were identified at the electron microscopic level (data not shown). Arrows point to the main axons.

cells, as identified by their characteristic thorny excrescences. Synaptic contact between a large mossy bouton and interneuron was observed only in a single case. Serial sections of single- and double-headed large mossy terminals indicated 30-40 release sites, all of which were presynaptic to the same single postsynaptic pyramidal cell (Chicurel and Harris, 1992) (this study).

On the basis of these observations, we conclude that granule cells innervate their principal cell and interneuron targets via large mossy boutons and small en passant or filopodial terminals, respectively (Fig. 12). Because each of these terminals typically contacts a single neuron, the larger number of small terminals indicates that granule cells innervate substantially larger number of inhibitory interneurons than principal cells. The estimated ratio of interneurons versus principal cell targets of the mossy fibers is $1: 4$ to $1: 6$. Because this ratio is $1: 10$ to $1: 20$ for cortical pyramidal cells (Kisvárday et al., 1986; Gulyás et al., 1993; Sík et al., 1993; Douglas et al., 1995), we conclude that, on average, granule cells contact GABAergic targets $\sim 50$ times more frequently than other cortical principal cells.

\section{Functional implications}

Our anatomical examinations indicate that granule cells innervate their postsynaptic pyramidal and GABAergic interneuron partners by morphologically distinct presynaptic terminals. These terminal types may not only exert differential effects on their postsynaptic targets but may also have distinct mechanisms for transmitter reuptake and for presynaptic control of transmitter release. In support of the latter possibility, small presynaptic terminals innervating presumed interneurons in stratum lucidum have recently been shown to express presynaptic mGluR7b receptors, whereas the majority of large terminals lacked this receptor (Shigemoto et al., 1997). The large and small terminals may also express a different type of plasticity. Tetanic stimulation of the mossy fibers is known to induce a presynaptic form of 
long-term potentiation (LTP) in CA3 pyramidal cells (Jaffe and Johnston, 1990; Zalutsky and Nicoll, 1990; Derrick and Martinez, 1996; Urban et al., 1996). Recent works suggest that mossy fiber stimulation-induced LTP may be absent in interneurons (Maccaferri et al., 1998). The cause of this differential LTP expression may be found in the different molecular compositions of the large and small presynaptic boutons.

The granule cell to mossy cell and pyramidal cell excitatory connectivity is characterized by a very limited convergence. In our study, even neighboring granule cells failed to converge on common pyramidal cell targets. In contrast, previous studies have already indicated that hundreds or perhaps thousands of granule cells may converge on the horizontal spiny interneurons of stratum lucidum (Gulyás et al., 1992; Hsu and Buzsáki, 1993). Convergence of granule cells on interneurons was also common in our experiments.

The low probability of principal cell innervation by granule cells can also be contrasted with the higher probability of interneuron innervation in both the hilus and the CA3 region. This anatomical arrangement may explain why increased granule cell activity, in general, is associated with decreased excitability of CA3 pyramidal cells (Bragin et al., 1995a,b; Penttonen et al., 1997). Such a mechanism would insure that only a selected small group of pyramidal cells will be discharged by the dentate input. Threshold depolarization, in principle, can be achieved by the coincident activity of granule cells on a common pyramidal cell target. However, the slow firing rate of granule cells $(p<0.5 \mathrm{~Hz})$ (Jung and McNaughton, 1993), coupled with the extremely low convergence of granule cells onto pyramidal cells and strong feed-forward inhibition, suggests that the probability of such coincident discharge is exceptionally low. These considerations suggest that in the intact brain, transmission of information from the dentate gyrus to the Ammon's horn may be provided by concerted release of the neurotransmitter from a single mossy bouton (Henze et al., 1997). This single granule cell-principal cell spike transmission may be facilitated by subcortical neurotransmitters and by the direct, highly divergent excitatory perforant path afferents.

\section{REFERENCES}

Acsády L, Katona I, Gulyás AI, Shigemoto R, Freund TF (1997) Immunostaining for substance $\mathrm{P}$ receptor labels GABAergic cells with distinct termination patterns in the hippocampus. J Comp Neurol 378:320-336.

Amaral DG (1978) A Golgi study of cell types in the hilar region of the hippocampus in the rat. J Comp Neurol 182:851-914.

Amaral DG (1979) Synaptic extensions from the mossy fibers of the fascia dentata. Anat Embryol 155:241-251.

Amaral DG, Dent JA (1981) Development of the mossy fibers of the dentate gyrus: I. A light and electron microscopic study of the mossy fibers and their expansions. J Comp Neurol 195:51-86.

Amaral DG, Witter MP (1989) The three-dimensional organization of the hippocampal formation: a review of anatomical data. Neuroscience 31:571-591.

Amaral DG, Ishizuka N, Claiborne B (1990) Neuron numbers and the hippocampal network. In: Progress in brain research. Understanding the brain through the hippocampus: the hippocampal region as a model for studying structure and function (Storm-Matisen J, Zimmer J, Ottersen OP, eds), pp 1-11. Elsevier: New York.

Baimbridge KG, Miller JJ (1982) Immunohistochemical localization of calcium-binding protein in the cerebellum, hippocampal formation and olfactory bulb of the rat. Brain Res 245:223-229.

Baude A, Nusser Z, Roberts JD, Mulvihill E, McIlhinney RA, Somogyi $P$ (1993) The metabotropic glutamate receptor (mGluR1 alpha) is concentrated at perisynaptic membrane of neuronal subpopulations as detected by immunogold reaction. Neuron 11:771-787.

Blackstad TW, Kjaerheim A (1961) Special axo-dendritic synapses in the hippocampal cortex: electron and light microscopic studies on the layer of mossy fibers. J Comp Neurol 117:113-159.

Bragin A, Jando G, Nadasdy Z, Hetke J, Wise K, Buzsáki G (1995a) Gamma frequency $(40-100 \mathrm{~Hz})$ patterns in the hippocampus of the behaving rat. J Neurosci 15:47-60.

Bragin A, Jando G, Nadasdy Z, van Landeghem M, Buzsáki G (1995b) Dentate EEG spikes and associated interneuronal population bursts in the hippocampal hilar region of the rat. J Neurophysiol 73:1691-1705.

Buckmaster PS, Wenzel HJ, Kunkel DD, Schwartzkroin PA (1996) Axon arbors and synaptic connections of hippocampal mossy cells in the rat in vivo. J Comp Neurol 366:270-292.

Chicurel ME, Harris KM (1992) Three-dimensional analysis of the structure and composition of CA3 branched dendritic spines and their synaptic relationship with mossy fiber boutons in the rat hippocampus. J Comp Neurol 325:169-182.

Chrobak JJ, Buzsáki G (1996) High-frequency oscillations in the output networks of the hippocampal-entorhinal axis of the freely behaving rat. J Neurosci 16:3056-3066.

Claiborne BJ, Amaral DG, Cowan WM (1986) A light and electron microscopic analysis of the mossy fibers of the rat dentate gyrus. J Comp Neurol 246:435-458.

Deller T, Léránth C (1990) Synaptic connections of neuropeptide-Y (NPY) immunoreactive neurons in the hilar area of the rat hippocampus. J Comp Neurol 300:433-447.

Deller T, Nitsch R, Frotscher M (1994) Associational and commissural afferents of parvalbumin-immunoreactive neurons in the rat hippocampus: a combined immunocytochemical and PHA-L study. J Comp Neurol 350:612-622.

Derrick BE, Martinez Jr JL (1996) Associative, bidirectional modifications at the hippocampal mossy fiber-CA3 synapse. Nature 381:429-434

Douglas RJ, Koch C, Mahowald M, Martin KA, Suarez HH (1995) Recurrent excitation in neocortical circuits. Science 269:981-985.

Drake CT, Terman GW, Simmons ML, Milner TA, Kunkel DD, Schwartzkroin PA, Chavkin C (1994) Dynorphin opioids present in dentate granule cells may function as retrograde inhibitory transmitters. J Neurosci 14:3736-3750.

Freund TF, Buzsáki G (1996) Interneurons of the hippocampus. Hippocampus 6:347-470.

Frotscher M (1985) Mossy fibers form synapses with identified pyramidal basket cells in the CA3 region of the guinea-pig hippocampus: a combined Golgi-electron microscope study. J Neurocytol 14:245-259.

Frotscher M (1989) Mossy fiber synapses on glutamate decarboxylaseimmunoreactive neurons: evidence for feed-forward inhibition in the CA3 region of the hippocampus. Exp Brain Res 75:441-445.

Geiger JRP, Lübke J, Roth A, Frotscher M, Jonas P (1997) Submillisecond AMPA receptor-mediated signaling at a principal cell-interneuron synapse. Neuron 18:1009-1023.

Gulyás AI, Miettinen R, Jacobowitz DM, Freund TF (1992) Calretinin is present in non-pyramidal cells of the rat hippocampus-I. A new type of neuron specifically associated with the mossy fibre system. Neuroscience 48:1-27.

Gulyás AI, Miles R, Sík A, Tóth K, Tamamaki N, Freund TF (1993) Hippocampal pyramidal cells excite inhibitory neurons through a single release site. Nature 366:683-687.

Gulyás AI, Hájos N, Freund TF (1996) Interneurons containing calretinin are specialized to control other interneurons in the rat hippocampus. J Neurosci 16:3397-3411.

Halasy K, Somogyi P (1993) Subdivisions in the multiple GABAergic innervation of granule cells in the dentate gyrus of the rat hippocampus. Eur J Neurosci 5:411-429.

Han ZS, Buhl EH, Lorinczi Z, Somogyi P (1993) A high degree of spatial selectivity in the axonal and dendritic domains of physiologically identified local-circuit neurons in the dentate gyrus of the rat hippocampus. Eur J Neurosci 5:395-410.

Henze DA, Urban NN, Barrionuevo G (1997) Origin of the apparent asynchronous activity of hippocampal mossy fibers. J Neurophysiol 78:24-30.

Hsu M, Buzsáki G (1993) Vulnerability of mossy fiber targets in the rat hippocampus to forebrain ischemia. J Neurosci 13:3964-3979.

Jaffe D, Johnston D (1990) Induction of long-term potentiation at hippocampal mossy-fiber synapses follows a Hebbian rule. J Neurophysiol 64:948-960.

Jonas P, Major G, Sakmann B (1993) Quantal components of unitary EPSCs at the mossy fibre synapse on CA3 pyramidal cells of rat hippocampus. J Physiol (Lond) 472:615-663. 
Jung MW, McNaughton BL (1993) Spatial selectivity of unit activity in the hippocampal granular layer. Hippocampus 3:165-182.

Kisvárday ZF, Martin KA, Freund TF, Maglóczky Z, Whitteridge D, Somogyi P (1986) Synaptic targets of HRP-filled layer III pyramidal cells in the cat striate cortex. Exp Brain Res 64:541-552.

Léránth C, Malcolm AJ, Frotscher M (1990) Afferent and efferent synaptic connections of somatostatin-immunoreactive neurons in the rat fascia dentata. J Comp Neurol 295:111-122.

Li X-G, Somogyi P, Ylinen A, Buzsáki G (1994) The hippocampal CA3 network: an in vivo intracellular labeling study. J Comp Neurol 339:181-208.

Livsey CT, Vicini S (1992) Slower spontaneous excitatory postsynaptic currents in spiny versus aspiny hilar neurons. Neuron 8:745-755.

Lorente de Nó R (1934) Studies of the structure of the cerebral cortex. II. Continuation of the study of the ammonic system. J Psychol Neurol 46:113-177.

Maccaferri G, Toth K, Mcbain CJ (1998) Target specific expression of presynaptic mossy fiber plasticity. Science, in press.

McLean S, Rothman RB, Jacobson AE, Rice KC, Herkenham M (1987) Distribution of opiate receptor subtypes and enkephalin and dynorphin immunoreactivity in the hippocampus of squirrel, guinea pig, rat and hamster. J Comp Neurol 255:495-510.

Miles R (1990) Synaptic excitation of inhibitory cells by single CA3 hippocampal pyramidal cells of the guinea-pig in vitro. J Physiol (Lond) 428:61-77.

Nitsch R, Soriano E, Frotscher M (1990) The parvalbumin-containing nonpyramidal neurons in the rat hippocampus. Anat Embryol 181:413-425.

Penttonen M, Kamondi A, Sík A, Acsády L, Buzsáki G (1997) Feedforward and feed-back activation of the dentate gyrus in vivo during dentate EEG spikes and sharp wave bursts. Hippocampus 7:403-415.

Ramón y Cajal S (1911) Histologie de systeme nerveux de l'homme et des vertebres tomme II. Paris: Maloine.

Ribak CE (1992) Local circuitry of GABAergic basket cells in the dentate gyrus. In: The dentate gyrus and its role in seizures (Ribak CE, Gall CM, Mody I, eds), pp 29-49. Amsterdam: Elsevier.

Ribak CE, Seress L (1983) Five types of basket cell in the hippocampal dentate gyrus: a combined Golgi and electron microscopic study. J Neurocytol 12:577-597.

Ribak CE, Seress L (1988) A Golgi-electron microscopic study of fusiform neurons in the hilar region of the dentate gyrus. J Comp Neurol 271:67-78.

Rogers JH (1989) Two calcium-binding proteins mark many chick sensory neurons. Neuroscience 31:697-709.

Seress L, Léránth C (1996) Distribution of substance P-immunoreactive neurons and fibers in the monkey hippocampal formation. Neuroscience 71:633-650.

Scharfman HE (1994) EPSPs of dentate gyrus granule cells during epileptiform bursts of dentate hilar "mossy" cells and area CA3 pyramidal cells in disinhibited rat hippocampal slices. J Neurosci 14:6041-6057.

Scharfman HE, Kunkel DD, Scwartzkroin PA (1990) Synaptic connections of dentate granule cells and hilar neurons: results of paired intracellular recordings and intracellular horseradish peroxidase injections. Neuroscience 37:693-707.

Shigemoto R, Nakaya Y, Nomura S, Ogawa-Meguro R, Ohishi H, Kaneko T, Nakanishi S, Mizuno N (1993) Immunocytochemical localization of rat substance P receptor in striatum. Neurosci Lett 153:157-160.

Shigemoto R, Kinoshita A, Wada W, Nomura S, Ohishi H, Takada M, Flor PJ, Neki A, Abe T, Nakanishi S, Mizuno N (1997) Differential presynaptic localization of metabotropic glutamate receptor subtypes in the rat hippocampus. J Neurosci 17:7503-7522.

Sík A, Tamamaki N, Freund TF (1993) Complete axon arborization of a single CA3 pyramidal cell in the rat hippocampus, and its relationship with postsynaptic parvalbumin-containing interneurons. Eur J Neurosci 5:1719-1728.

Sík A, Penttonen M, Buzsáki G (1997) Interneurons in the hippocampal dentate gyrus: an in vivo intracellular study. Eur J Neurosci 9:573-588.

Soriano E, Frotscher M (1993) Spiny nonpyramidal neurons in the CA3 region of the rat hippocampus are glutamate-like immunoreactive and receive convergent mossy fiber input. J Comp Neurol 333:435-448.

Soriano E, Frotscher M (1994) Mossy cells of the rat fascia dentata are glutamate-immunoreactive. Hippocampus 4:65-70.

Steward O, Scoville SA (1976) Cells of origin of entorhinal cortical afferents to the hippocampus and fascia dentata of the rat. J Comp Neurol 169:347-370.

Swanson LW, Wyss JM, Cowan WM (1978) An autoradiographic study of the organization of intrahippocampal association pathways in the rat. J Comp Neurol 181:681-716.

Tamamaki N, Nojyo Y (1991) Crossing fiber arrays in the rat hippocampus as demonstrated by three-dimensional reconstruction. J Comp Neurol 303:435-442.

Urban NN, Barrionuevo G (1996) Induction of hebbian and nonhebbian mossy fiber long-term potentiation by distinct patterns of high-frequency stimulation. J Neurosci 16:4293-4299.

Ylinen A, Bragin A, Nádasdy Z, Jandó G, Szabó I, Sík A, Buzsáki G (1995) Sharp-wave-associated high-frequency oscillation $(200 \mathrm{~Hz})$ in the intact hippocampus: network and intracellular mechanisms. J Neurosci 15:30-46.

Zalutsky RA, Nicoll RA (1990) Comparison of two forms of long-term potentiation in single hippocampal neurons. Science 248:1619-1624. 